\title{
CrystEngComm
}

Check for updates

Cite this: DOI: 10.1039/c9ce01544b

\section{The multiple roles of carbonic anhydrase in calcium carbonate mineralization $\dagger$}

\author{
Carlos Rodriguez-Navarro, iD *a Özlem Cizer, ${ }^{b}$ Krzysztof Kudłacz, ${ }^{c}$ \\ Aurelia Ibañez-Velasco, ${ }^{a}$ Cristina Ruiz-Agudo, ${ }^{d}$ Kerstin Elert, ${ }^{a}$ \\ Alejandro Burgos-Cara (iD ${ }^{a}$ and Encarnacion Ruiz-Agudo (iD) ${ }^{a}$
}

\begin{abstract}
Carbonic anhydrase (CA), a ubiquitous enzyme that catalyzes the reversible hydration of $\mathrm{CO}_{2}$, is known to be involved in the formation of $\mathrm{CaCO}_{3}$ biominerals and is currently used for biomimetic $\mathrm{CO}_{2}$ mineral sequestration. However, its specific role(s) in calcium carbonate (bio)mineralization is poorly understood. Here we show that $\mathrm{CA}$ catalyzes the formation of the reactive precursors (i.e., $\mathrm{HCO}_{3}^{-}$and $\mathrm{CO}_{3}{ }^{2-}$ ions) required for mineralization, accelerates the precipitation of metastable amorphous calcium carbonates and their solution-mediated conversion into crystalline calcite, which grows via a non-classical nanoparticle aggregation mechanism that facilitates $\mathrm{CA}$ occlusion. $\mathrm{Ca}^{+}$and $\mathrm{CO}_{3}{ }^{2-}$ ions promote the partial unfolding and oligomerization of $\mathrm{CA}$, resulting in fibril- and sheet-like supramolecular assemblies that template nanostructured calcium carbonate crystallization. By losing its catalytic activity following the observed conformational changes, CA elicits a mechanism for arresting calcium carbonate mineralization. Our results show that CA can play multiple, until now unrecognized, critical roles, namely, as an enzyme and structural protein in $\mathrm{CaCO}_{3}$ biomineralization and also helps to explain the observed loss of enzymatic activity during ex situ $\mathrm{CO}_{2}$ mineral sequestration.
\end{abstract}

Received 30th September 2019, Accepted 8th November 2019

DOI: 10.1039/c9ce01544b

rsc.li/crystengcomm proteins) that modulate the formation and stabilization of liquid and amorphous calcium carbonate (ACC) precursors, ${ }^{3-10}$ as well as crystalline $\mathrm{CaCO}_{3}$ polymorphism, morphology, orientation/texture, and hierarchical structure. ${ }^{5,6}$ Such biomacromolecules are also involved in the formation of the nanogranular structure typically observed in carbonate biominerals and their biomimetics, ${ }^{6,11}$ are key for the development of their mesostructure, ${ }^{12,14}$ and can be occluded within crystalline phases, ${ }^{4,5}$ altogether contributing to their superior physico-chemical and mechanical properties. ${ }^{11}$ Chemists and material scientists have long been interested in mimicking this biomineralization strategy for the design and fabrication of bioinspired organic-inorganic materials with particular properties, shapes and functions. ${ }^{5,6}$ Despite recent progress, our current understanding of the role of biomacromolecules, particularly matrix proteins, in calcium carbonate biomineralization is however incomplete.

Carbonic anhydrase (CA) is one of the biomacromolecules involved in $\mathrm{CaCO}_{3}$ biomineralization. ${ }^{15} \mathrm{CA}$ is a member of the family of Zn-metaloenzymes (with the exception of the $\xi$-CA class, which includes $\mathrm{Cd}$ ) that catalyze the reversible reaction $\mathrm{CO}_{2}+\mathrm{H}_{2} \mathrm{O} \leftrightarrow \mathrm{HCO}_{3}^{-}+\mathrm{H}^{+}$, which is rate-determining for calcium carbonate precipitation and dissolution. ${ }^{2,16,17}$ The $\mathrm{Zn}^{2+}$ metal ion in CA is bound to three His amino acid residues and a water (or hydroxyl) molecule. In the presence of $\mathrm{CO}_{2}$, the following reactions take place leading to the 
formation of bicarbonate ions and protons concurrent with the regeneration of the CA molecule:

$$
\begin{gathered}
\mathrm{CA}: \mathrm{Zn}-\mathrm{H}_{2} \mathrm{O} \leftrightarrow \mathrm{CA}: \mathrm{Zn}-\mathrm{OH}^{-}+\mathrm{H}^{+} \\
\mathrm{CA}: \mathrm{Zn}-\mathrm{OH}^{-}+\mathrm{CO}_{2}+\mathrm{H}_{2} \mathrm{O} \leftrightarrow \mathrm{CA}: \mathrm{Zn}-\mathrm{H}_{2} \mathrm{O}+\mathrm{HCO}_{3}^{-} .
\end{gathered}
$$

At moderately to highly alkaline $\mathrm{pH}$, the resulting bicarbonate ions will readily deprotonate forming carbonate ions, which in the presence of calcium ions will enable the build-up of a sufficiently high supersaturation which results in fast calcium carbonate precipitation. ${ }^{17}$

CA is ubiquitous in living organisms and critical to many processes such as respiration, bone resorption and calcification, ion transport, $\mathrm{pH}$ regulation, and photosynthesis. ${ }^{18}$ Histochemical staining and CA-activity analyses have shown that both cellular and extracellular $\alpha$-CAs are involved in $\mathrm{CaCO}_{3}$ biomineralization, ${ }^{15,19-21}$ these proteins being considered as one of the molecules in the living world's minimal biomineralization toolkit. ${ }^{20}$ Proteomic analyses show that the $\alpha$-CA class is present in biomineral-related matrix proteins of several organisms such as mollusks, ${ }^{22,23}$ echinoderms, $^{20}$ corals, ${ }^{19,24}$ calcareous sponges, ${ }^{17}$ and avian eggshells. ${ }^{25} \alpha$-CA inhibitors such as azetazolamide either prevent or strongly decelerate calcium carbonate skeletogenesis in such organisms, ${ }^{15}$ demonstrating that this enzyme is critical for carbonate biomineralization. Furthermore, the $\alpha$-CA class and in particular the $\alpha$-CAII family are effective in the acceleration of the kinetics of $\mathrm{CO}_{2}$ capture and storage during biomimetic carbon sequestration via carbonate mineralization. ${ }^{26}$ This is due to the fact that $\alpha$-CA displays an extremely high catalytic efficiency for $\mathrm{CO}_{2}$ hydration (first-order rate constant $k_{\text {cat }} \sim 10^{6}$ $\mathrm{s}^{-1}$, which approaches the diffusion-controlled limit). ${ }^{27}$ However, the exact role (or roles) that CA plays in calcium carbonate (bio)mineralization is not known. ${ }^{19}$

In order to shed light on the effects of $\mathrm{CA}$ on $\mathrm{CaCO}_{3}$ mineralization, here we study calcium carbonate precipitation and phase transitions in small volume $(5-200 \mu \mathrm{L})$ calcium hydroxide solution droplets subjected to $\alpha$-CA-catalyzed carbonation according to the overall reaction $\mathrm{Ca}(\mathrm{OH})_{2}+\mathrm{CO}_{2}=$ $\mathrm{CaCO}_{3}+\mathrm{H}_{2} \mathrm{O}$, where the hydration of $\mathrm{CO}_{2}$ is the rate-limiting step. ${ }^{2,28}$ Each droplet provides a constrained environment and enables the in situ analysis of the evolution of the chemistry of the system $\left(\mathrm{pH},\left[\mathrm{Ca}^{2+}\right]\right.$ and $\left.\left[\mathrm{CO}_{3}{ }^{2-}\right]\right)$ as well as the kinetics and mechanisms of the different precipitation events and mineral phase transformations without interference from background electrolytes. ${ }^{28}$ Carbonation in the $\mathrm{Ca}(\mathrm{OH})_{2}-\mathrm{H}_{2} \mathrm{O}$ system has been shown to be relevant for several technological processes including $\mathrm{CO}_{2}$ mineral sequestration ${ }^{29}$ or the biomimetic synthesis of functional $\mathrm{CaCO}_{3}$ structures such as microlens arrays. ${ }^{30}$ However, as in the case of other in vitro systems thoroughly used for biomimetic calcium carbonate precipitation, such as the gas diffusion method based on $\left(\mathrm{NH}_{4}\right)_{2} \mathrm{CO}_{3}$ decomposition, ${ }^{5}$ its chemistry, specially $\mathrm{pH}$ values, might not be representative of in vivo biomineralization. Nonetheless, these in vitro systems limit the number of variables and offer invaluable mechanistic information regarding the effects of additives (e.g., proteins) on $\mathrm{CaCO}_{3}$ mineralization. ${ }^{4,5}$ In any case, it should be stressed that upon contact with $\mathrm{CO}_{2}$ the initial $\mathrm{pH}$ $\sim 12.4$ in our system drops to values $(\mathrm{pH} \sim 8.2)$ of the same order of magnitude as physiological $\mathrm{pH}$ values in biomineralforming organisms. ${ }^{7,31}$ The initial total [Ca] in our system is $\sim 20$ $\mathrm{mM},{ }^{28}$ a value close to reported physiological calcium concentrations in marine organisms producing $\mathrm{CaCO}_{3}$ skeletons (e.g., $\sim 10 \mathrm{mM} \mathrm{Ca}^{2+}$ in extrapallial fluid of mollusks). ${ }^{7}$ Note also that the hydration of $\mathrm{CO}_{2}$ at $\mathrm{pH}>8.5$ primarily occurs via the reaction $\mathrm{CO}_{2}+\mathrm{OH}^{-}=\mathrm{HCO}_{3}^{-}$(second-order rate constant of $\sim 10^{4} \mathrm{M}^{-1} \mathrm{~s}^{-1}$ at $25{ }^{\circ} \mathrm{C}$ ), which is significantly faster than the reaction $\mathrm{CO}_{2}+\mathrm{H}_{2} \mathrm{O}=\mathrm{HCO}_{3}{ }^{-}+\mathrm{H}^{+}$taking place at close to neutral $\mathrm{pH}$ values (second-order rate contact of $6 \times 10^{-4} \mathrm{M}^{-1} \mathrm{~s}^{-1}$ at 25 $\left.{ }^{\circ} \mathrm{C}\right) .{ }^{32}$ Despite its high rate constant, the former hydration reaction is known to be rate-limiting for $\mathrm{CaCO}_{3}$ precipitation, ${ }^{15}$ and can be catalyzed by CA (second-order rate constant of $\sim 10^{8}$ $\mathrm{M}^{-1} \mathrm{~s}^{-1}$ at $25^{\circ} \mathrm{C}$ and $\left.\mathrm{pH} \geq 9\right) .{ }^{27}$

In addition to ex situ analyses of precipitates using a range of analytical techniques and the study of the protein conformational changes that took place during precipitation of carbonates, we also performed in situ analyses of calcite crystal growth at the nanoscale and $\mathrm{Ca}^{2+}$ potentiometric titration experiments where precipitation of calcium carbonate phases in bulk solution in the absence or presence of CA took place (see Methods). Altogether, our results show that CA plays multiple roles in $\mathrm{CaCO}_{3}$ mineralization that are relevant for both $\mathrm{CO}_{2}$ mineral sequestration and calcium carbonate biomineralization.

\section{Results}

\section{Formation and transformation of ACC in the presence of CA}

In situ optical microscopy (OM) analyses show that solution droplets dosed with $\geq 0.6 \mu \mathrm{M}$ CA led to the instantaneous formation of an iridescent ACC film at the air-solution interface fully covering the droplet, which after 3-5 $\mathrm{min}$ cracked due to evaporative shrinking (Fig. 1a). Within the film, dendritic aggregates of submicrometer particles (Fig. 1b and S1 $\dagger$ ) and banded convoluted structures (Fig. 1c) were observed, which were absent in CA-free runs. $^{28}$ Precipitates were amorphous as shown by the lack of birefringence and the distinctive features of Raman spectra (Fig. 1d). ${ }^{28}$ After ca. 6-11 min, depending on droplet volume (longer times in bigger droplets; Fig. 1e), micrometer-sized $\mathrm{CaCO}_{3}$ crystals (scarce, $\leq 5 \%$, vaterite spherulites and abundant, $\geq 95 \%$, calcite rhombohedra) surrounded by precipitate-free haloes formed at the expense of the iridescent ACC film (Fig. 1f, S1 and S2 $\dagger$ ). The time for the formation of crystalline phases at the air-solution interface was reduced by $38 \pm 4 \%$ in CA-containing runs as compared with CA-free runs (Fig. 1e). As the droplet edge retracted during drying of CA-containing droplets, iridescent ACC films lacking any convoluted structure formed on the substrate ( $\mathrm{Si}$ wafers or glass slides) (Fig. 1g), as also occurs in CA-free runs. $^{28}$ Field emission scanning electron microscopy 

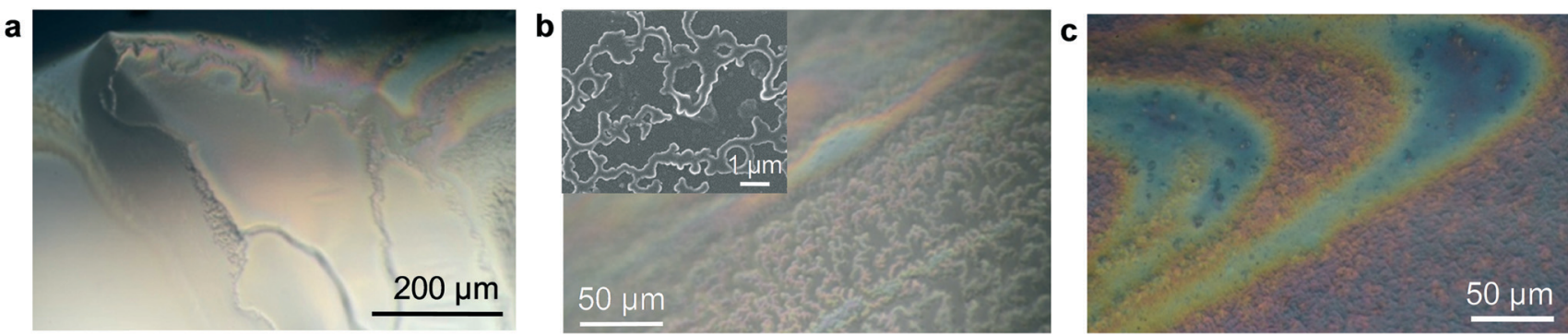

d

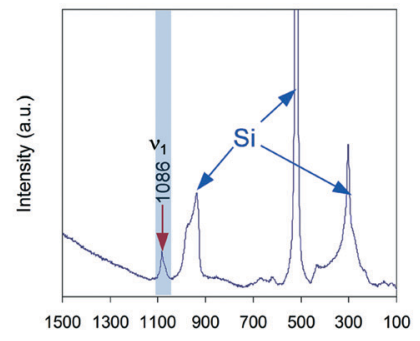

Raman shift $\left(\mathrm{cm}^{-1}\right)$ e

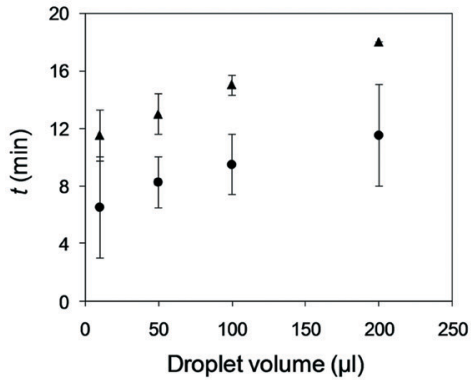

f

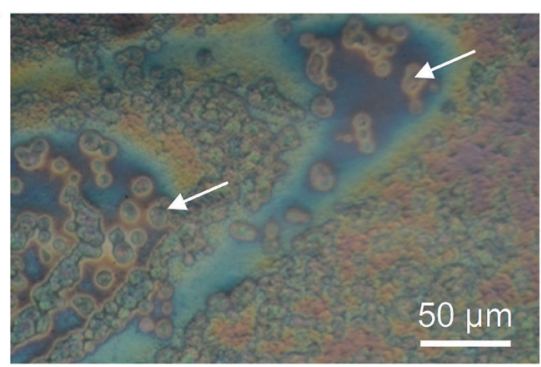

g

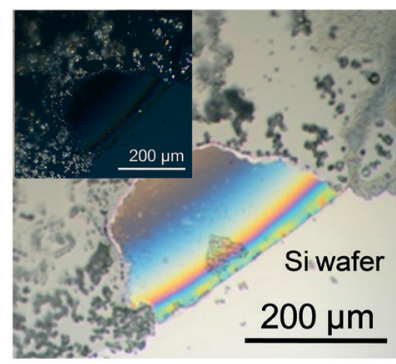

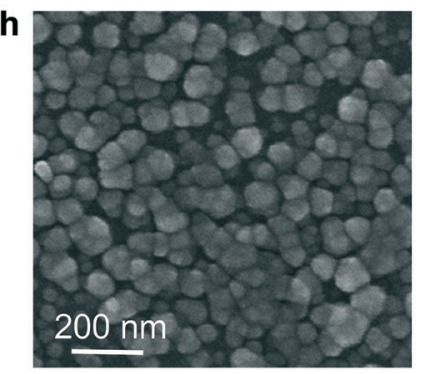

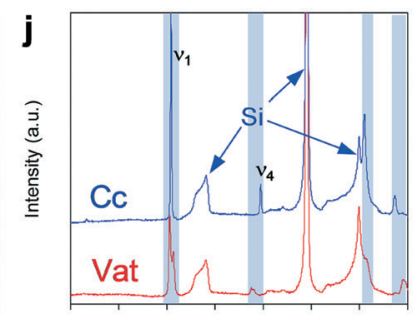

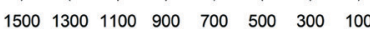

Raman shift $\left(\mathrm{cm}^{-1}\right)$

Fig. 1 Precipitates formed in $\mathrm{Ca}(\mathrm{OH})_{2}$ solution droplets dosed with $1.5 \mu \mathrm{M} \mathrm{CA}$. (a) OM photomicrograph of the iridescent ACC film at the airsolution interface showing drying cracks. (b) High magnification OM image of the ACC film and dendritic ACC aggregates (FESEM image of the dendritic ACC structure in the inset). (c) Convoluted banded structure of the iridescent ACC film covering the solution droplet. (d) Raman spectrum of ACC (shaded areas). (e) Elapsed time for the first appearance of crystalline $\mathrm{CaCO}_{3}$ after ACC. Symbols: $\bullet=$ solution with CA; $\Delta=\mathrm{CA}-$ free solution. (f) The same area in (c) after the beginning of ACC-to-crystalline $\mathrm{CaCO}_{3}$ conversion. Arrows show $\mathrm{crystalline} \mathrm{CaCO}_{3}$ surrounded by precipitate-free haloes. (g) OM image of precipitate-free areas formed after dissolution of ACC and concurrent precipitation of aggregates of calcite and minor vaterite. The droplet edge (center) shows an iridescent ACC film (crossed-polar image in the inset). (h) FESEM detail of the iridescent ACC film in (g). (i) Droplet edge showing iridescent patches of the ACC film with circular precipitate-free halos surrounding calcite (CC) and scarce vaterite (Vat). (j) Raman spectra of calcite and vaterite in (i). The shaded areas mark the calcium carbonate bands. All OM photomicrographs were collected under reflected light.

(FESEM) observations showed that the ACC film was made up of nearly-spherical nanoparticles $30-100 \mathrm{~nm}$ in size (Fig. 1h). Over time, calcite rhombohedra and some vaterite spherulites developed at the expense of the dissolution of the ACC film deposited on the substrate, resulting in crystals $\sim 1-10 \mu \mathrm{m}$ in size surrounded by precipitate-free haloes (Fig. 1i). Micro-Raman spectroscopy confirmed the formation of such crystalline phases (Fig. 1j).

FESEM observations showed that in the absence of CA, newly formed calcite crystals were up to $\sim 5 \mu \mathrm{m}$ in size and displayed well-developed rhombohedral faces (Fig. 2a). In contrast, those formed in the presence of CA were larger and elongated parallel to the $c$-axis (up to $\sim 10 \mu \mathrm{m}$ long), and displayed additional curved edges and rough stepped faces (Fig. 2b, $\mathrm{c}$ and S3a†) with a nanogranular structure made up of nanoparticles $\sim 30-60 \mathrm{~nm}$ in size (inset in Fig. 2c), similar to that observed in a range of biominerals. ${ }^{6,33}$ High magnification FESEM observations of the apparently smooth $\{10.4\}$ calcite faces also disclosed a nanogranular surface structure made up of nanoparticles $\sim 30-$ $60 \mathrm{~nm}$ in size, most evident at the ridges between neighboring $\{10.4\}$ faces (Fig. 2d and S3b $\uparrow$ ), as well as at the edge of curved macrosteps (Fig. 2e), with a step height of $\sim 50 \mathrm{~nm}$, a value similar to the diameter of the nanoparticles. Isolated or aggregated spherical nanoparticles were also observed on the terraces (Fig. 2e, S3c and d广). Film-like CA structures were also observed on the surface of calcite crystals (Fig. 2d). In situ high magnification observation of the carbonation and evaporation of CA-dosed $\mathrm{Ca}(\mathrm{OH})_{2}$ solution droplets placed in the chamber of an environmental SEM (ESEM) showed that calcite crystals formed after ACC during droplet drying (Fig. 2f) were typically covered by CA films and fibrils (Fig. $2 \mathrm{~g}$ and details in Fig. $2 \mathrm{~h}$ and S4†). Energy dispersive X-ray spectrometry (EDS) microanalysis showed a higher $\mathrm{C} / \mathrm{Ca}$ peak intensity ratio in fibril/film-covered calcite crystals than that in bare ones (Fig. $\mathrm{S} 4 \dagger$ ), confirming that the film and fibril structures were CA (i.e., the only organic additive in our system). 

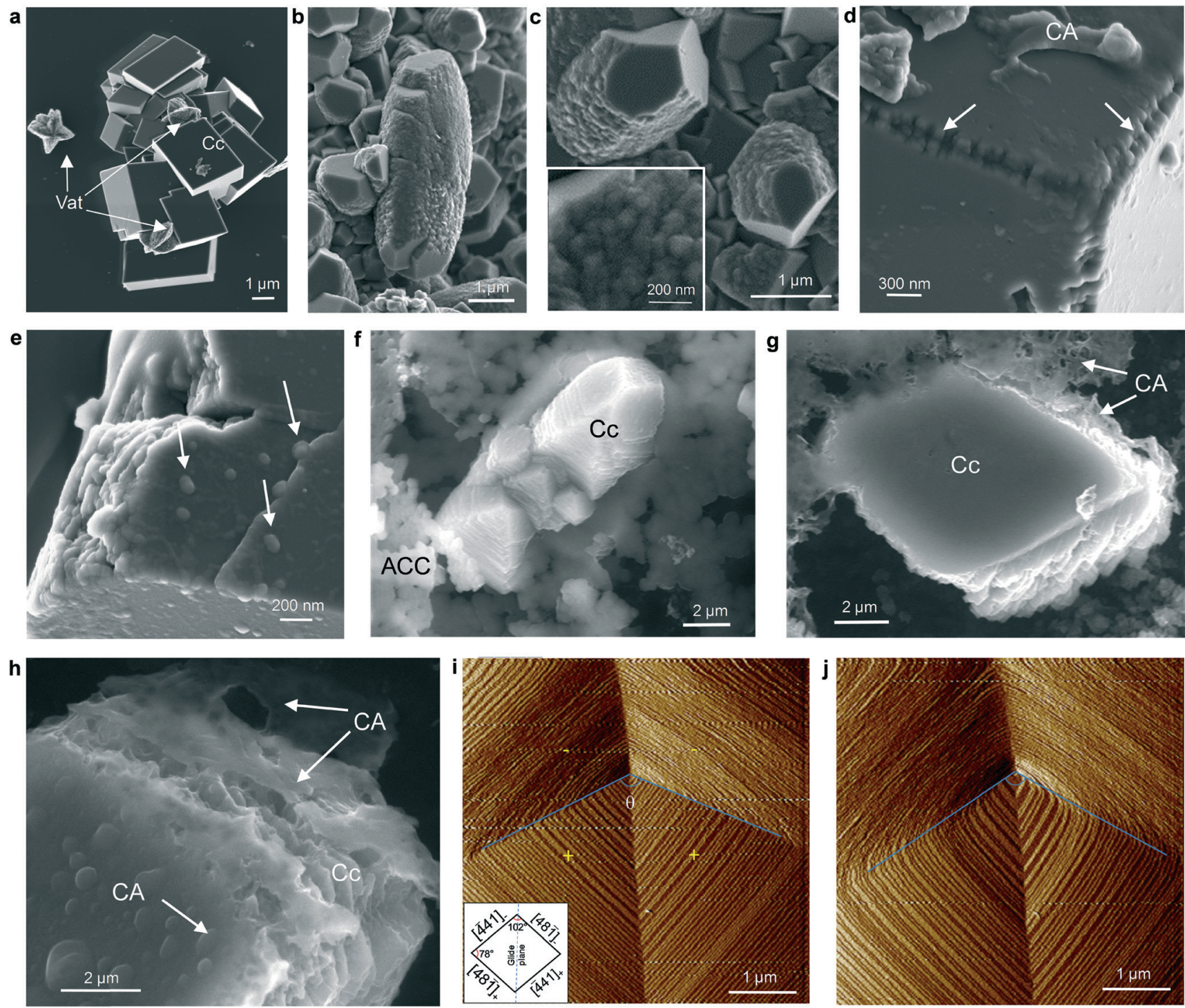

Fig. 2 Micro/nanoscopic features of precipitates. (a) FESEM image of well-formed calcite rhombohedra and disk-/star-shaped vaterite structures in CA-free (control) runs. (b-h) Calcite crystals in $1.5 \mu \mathrm{M}$ CA-inclusive runs: (b) spindle-like calcite (center). (c) Calcite rhombohedra with stepped, rounded faces and a nanogranular structure (details in the inset). (d) Calcite rhombohedron with surface deposits of CA and ridges between vicinal $\{10.4\}$ faces showing pseudo-spherical particles $\sim 30-60 \mathrm{~nm}$ in size (arrows). (e) Nanogranular structure of rhombohedral faces (terraces) and edges of rounded macrosteps, showing scattered nanoparticles ( 30-60 nm in diameter) (arrows). ESEM images of: (f) ACC nanoparticles in contact with a calcite crystal showing stepped faces and rounded edges, (g) calcite surrounded by CA films, and (h) details of the calcite rhombohedron covered by a CA film. ( $i$ and j) In situ fluid cell AFM deflection images of a growth hillock: developed in the absence of CA (i) and the same hillock 1 min after injection of the growth solution with $1.5 \mu \mathrm{M}$ CA (j). Note the rounding of the obtuse (-) steps. The inset in (i) shows a scheme of the directions of acute (-) and obtuse (+) steps. The angle $\theta$ between acute and obtuse sectors is indicated. Legend: Cc, calcite; Vat, vaterite; ACC, amorphous calcium carbonate; CA, carbonic anhydrase.

\section{In situ fluid cell atomic force microcopy (AFM) analysis}

To disclose how CA affects the growth and morphological development of calcite crystals, we performed in situ fluid cell AFM imaging of a freshly cleaved (10.4) calcite rhombohedral face exposed to the growth solution, which had moderately alkaline $\mathrm{pH}$ and supersaturation (see Methods). We are aware that these experimental conditions do not represent those of the above-described experimental results (high supersaturation resulting in the formation of amorphous precursors) or those relevant for calcium carbonate biomineralization (which commonly involves amorphous precursors). ${ }^{4,5,10,14}$ However, these experiments can provide important information to disclose additive-crystal interactions at the nanoscale. ${ }^{34}$ AFM images showed that the morphology of dislocation hillocks changed from the standard pyramidal structure (Fig. 2i) in CAfree runs to a distorted one in the presence of $1.5 \mu \mathrm{M} \mathrm{CA}$ (Fig. 2j). In the latter case, the sectors limited by acute (-) steps acquired a rounded morphology and their piling up led to step bunching. Conversely, obtuse steps remained straight, and 
displayed well-developed terraces without detectable bunching. Rounding and bunching of acute steps is known to be manifested macroscopically by the rounding of edges limiting neighboring stepped faces, whereas the edges of neighboring $\{10.4\}$ faces formed by the obtuse steps remain straight, ${ }^{34}$ as shown by our FESEM observations (Fig. 2b, c and f).

Interestingly, the speed of obtuse step advancement increased from $14.7 \pm 1.4 \mathrm{~nm} \mathrm{~s}^{-1}$ in control runs to $20.8 \pm 2.6$ $\mathrm{nm} \mathrm{s}^{-1}$ in the presence of CA, whereas the angle $\theta$ that bisects the two equivalent flanks of the growth hillock decreased from $\sim 135^{\circ}$ to $\sim 110^{\circ}$. In contrast, the speed of acute step advancement was reduced from $5.7 \pm 0.9 \mathrm{~nm} \mathrm{~s}^{-1}$ in control runs to $3.3 \pm 0.7 \mathrm{~nm} \mathrm{~s}^{-1}$ in the presence of CA.

Finally, we observed no CA surface precipitate. This is likely because the short residence time of the CA-containing solution in the AFM fluid cell $(\sim 15 \mathrm{~min})$ did not enable the oligomerization of the protein and the formation of insoluble CA structures (this occurs after $\sim 15-30 \mathrm{~min}$, see TEM results below).

\section{In situ X-ray diffraction analysis of $\mathrm{CaCO}_{3}$ crystallization}

In situ X-ray diffraction (XRD) analyses were performed using $\sim 200 \mu \mathrm{L} \mathrm{Ca}(\mathrm{OH})_{2}$ solution droplets exposed to atmospheric $\mathrm{CO}_{2}$. Time-resolved XRD patterns show two broadened maxima at $\sim 20-35^{\circ} 2 \theta$ and $40-45^{\circ} 2 \theta$ (Fig. $3 a$ and $b$ ), corresponding to the sum of the scattering intensities of water and ACC phase(s). ${ }^{28}$ The 104 Bragg peak of calcite was first detected after $\sim 168 \pm 3, \sim 85 \pm 3$ and $\sim 57 \pm 3 \mathrm{~min}$ in the presence of $0.0,0.8$ and $1.5 \mu \mathrm{M}$ CA, respectively. These results are consistent with our $\mathrm{OM}$ observations of the first appearance of crystalline $\mathrm{CaCO}_{3}$ after ACC, showing smaller elapsed times for the formation of calcite in the presence of 1.5 $\mu \mathrm{M}$ CA than those in CA-free runs (Fig. 1e). As the amount of calcite increased, a clear decrease in the amount of ACC was observed (Fig. 3c). Fig. 3c shows that the transformation of ACC into calcite was completed earlier in the presence of CA than in CA-free runs. No vaterite Bragg peaks were detected, most likely due to the low concentration of this phase (i.e., below the $\pm 5 \%$ detection limit of XRD).

\section{Time evolution of the system's chemistry}

To further disclose the effects of CA on the formation and transformation of ACC in solution, we studied the time evolution of $\mathrm{pH},[\mathrm{Ca}]_{\text {free }}$ and total dissolved $\left[\mathrm{CO}_{2}\right]$ (i.e., total DIC) in droplets of $\mathrm{Ca}(\mathrm{OH})_{2}$ solution $(200 \mu \mathrm{L})$ subjected to carbonation in air in the presence of $1.5 \mu \mathrm{M}$ CA. From these data, we calculated the saturation index, SI, with respect to hydrated ACC, anhydrous ACC, vaterite and calcite ${ }^{28}$ (see Methods). Fig. 4a shows that both $\mathrm{pH}$ and $[\mathrm{Ca}]_{\text {free }}$ experienced a reduction right after air exposure, as also observed in enzyme-free systems. ${ }^{28}$ In the presence of CA, however, $[\mathrm{Ca}]_{\text {free }}$ dropped from the initial $\sim 18 \mathrm{mM}$ to $\sim 3 \mathrm{mM}$ in just one minute, whereas in the CA-free system it took $\sim 80$ min to reach such a low $[\mathrm{Ca}]_{\text {free }}$ value. According to our OM results, this is due to the rapid precipitation of ACC, which following our previous study, we have called stage $\mathrm{I}^{28}$
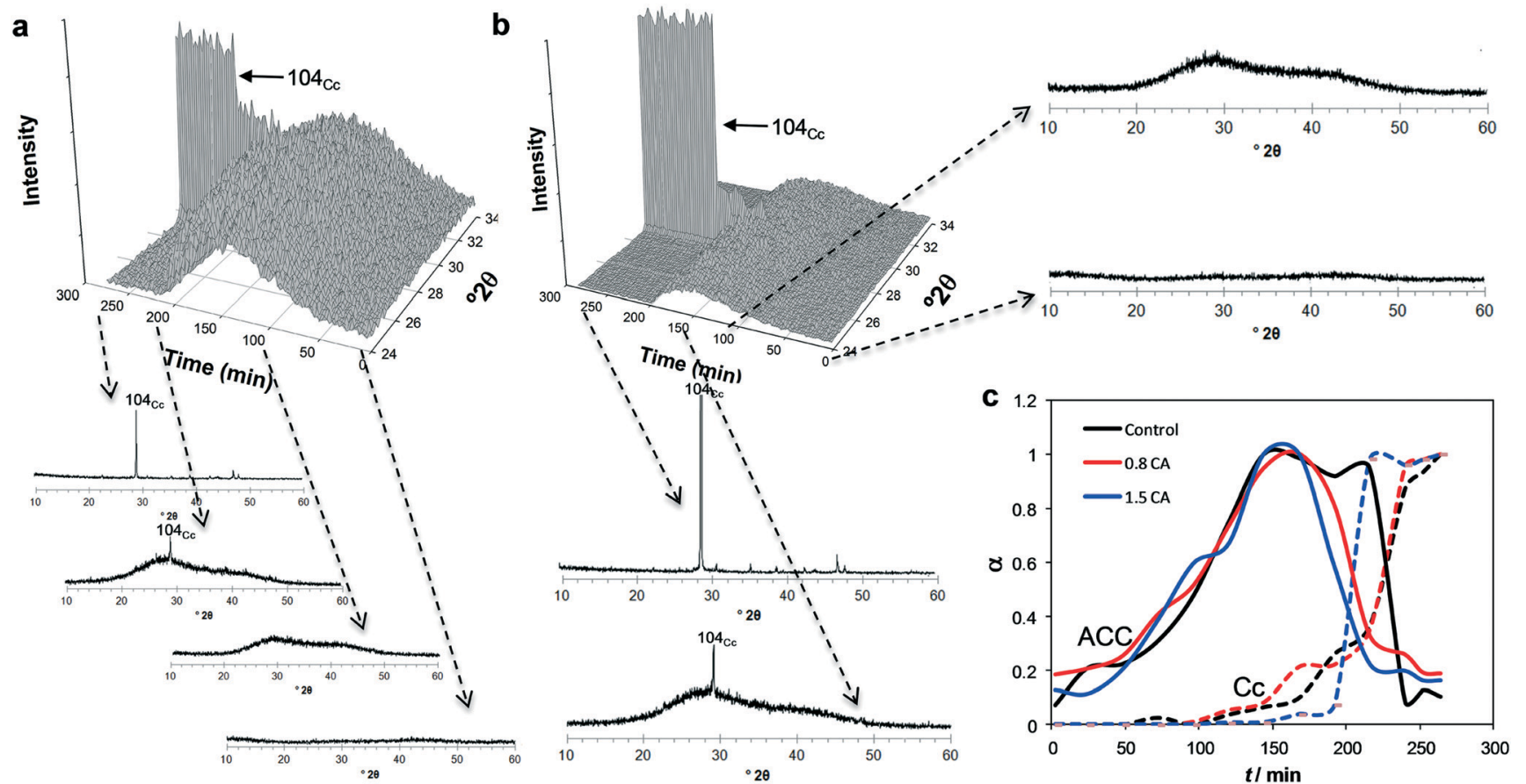

Fig. 3 Time resolved XRD analysis of calcium carbonate precipitation. XRD patterns of $\mathrm{Ca}(\mathrm{OH})_{2}$ saturated solution droplets without (a) and with $1.5 \mu \mathrm{M}$ CA (b) exposed to atmospheric $\mathrm{CO}_{2}$. Note the increase in the background intensity due to the formation of ACC and its decrease upon calcite precipitation (best seen in individual XRD patterns, in the inset). The 104 Bragg peak of calcite (Cc) is indicated. (c) Time evolution of the fractional amount $(\alpha)$ of ACC (solid lines) and calcite, Cc (dashed lines) in the control (CA-free) and runs with CA dosed at different concentrations. 

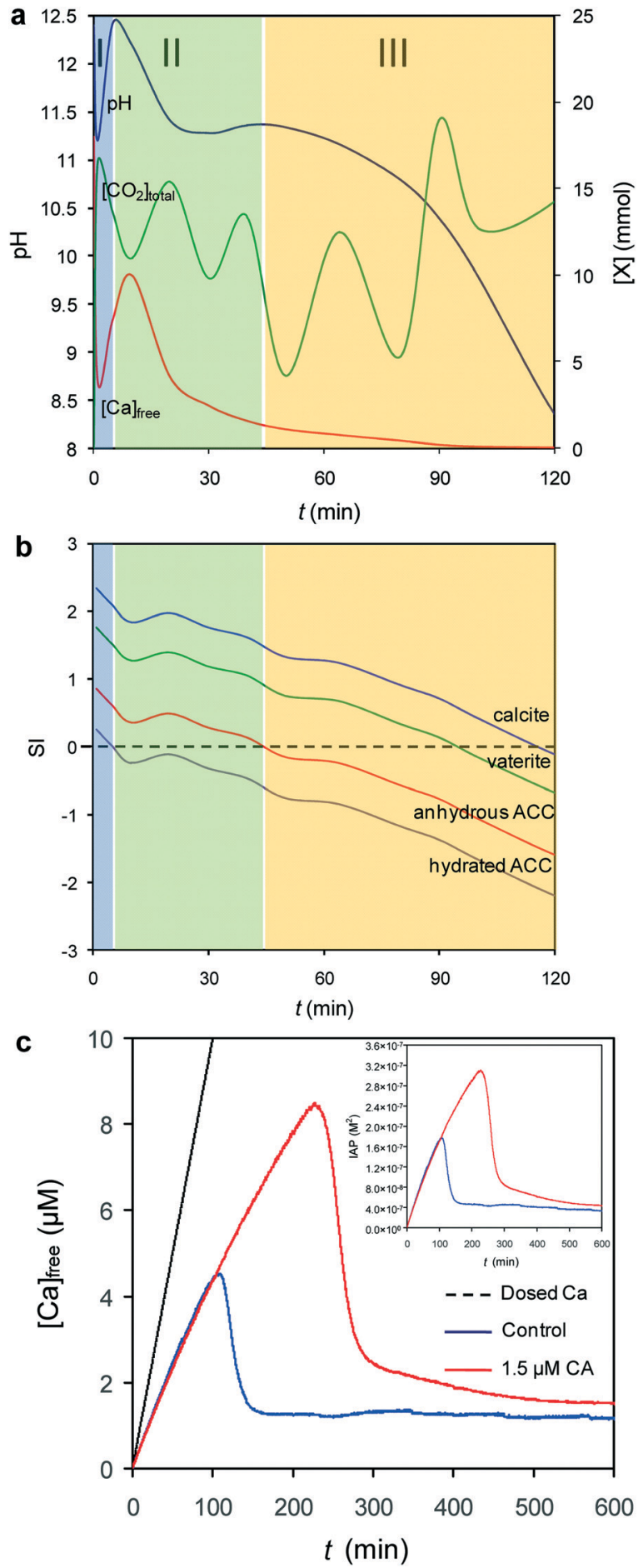

Fig. 4 Time-evolution of solution chemistry. (a) $\mathrm{pH}$ (blue line), [Ca $]_{\text {free }}$ (red line) and total dissolved $\mathrm{CO}_{2},\left[\mathrm{CO}_{2}\right]_{\text {total }}$ (green line) evolution during calcium carbonate precipitation in $200 \mu \mathrm{L}$ droplets of $\mathrm{Ca}(\mathrm{OH})_{2}$ saturated solution dosed with $1.5 \mu \mathrm{M} \mathrm{CA}$. The shaded areas mark the different stages (I, II, and III) of precipitation (see text for details). (b) The corresponding time evolution of the saturation index (SI) with respect to different calcium carbonate phases. Values of $\mathrm{SI}>0$ and $\mathrm{SI}$ $<0$ indicate supersaturation and undersaturation with respect to a particular solid phase, respectively (calculated using PHREEQC). (c) Results of calcium potentiometric titration experiments showing the time evolution of free $\mathrm{Ca}$ (time-resolved changes of IAP in the inset) of representative control and enzyme-including runs. The black line shows the amount of $\mathrm{Ca}$ dosed.
After a few minutes, $[\mathrm{Ca}]_{\text {free }}$ increased to $\sim 10 \mathrm{mM}$, implying dissolution of a precursor calcium carbonate phase, and subsequently decreased to a value of $\sim 2 \mathrm{mM}$ due to precipitation of another (less soluble and therefore more stable) calcium carbonate phase. In parallel, the $\mathrm{pH}$ first rose to $\sim 12.4$ and subsequently dropped to $\sim 11.3$. This second precipitation stage, which we call stage II, corresponds to the precipitation of another form of ACC (see below) following the dissolution of ACC formed in stage I. At longer elapsed times, $[\mathrm{Ca}]_{\text {free }}$ continued to drop and the $\mathrm{pH}$ started to slightly increase, marking the transition to stage III, which corresponds to the transformation of ACC into crystalline phases (calcite and minor vaterite). The growth of these crystalline phases led to the continuous reduction in $[\mathrm{Ca}]_{\text {free }}$ and $\mathrm{pH}$. In parallel and over the course of the experiment, the total dissolved $\left[\mathrm{CO}_{2}\right]$ experienced a significant yet not continuous rise from $\sim 0 \mathrm{mM}$ to a maximum of $\sim 30 \mathrm{mM}$. The observed fluctuations confirm that different precipitation and dissolution events occurred over time. Fig. $4 \mathrm{~b}$ shows that the system eventually reached undersaturation, first with respect to hydrated ACC, and subsequently with respect to anhydrous ACC, marking the end of stage I and II, respectively. These results show that calcium carbonate precipitation in the presence of CA occurred through three stages marking the formation and dissolution of three phases with increasing stability and that phase transitions took place via a dissolution-precipitation mechanism, in full agreement with Ostwald's rule of stages. ${ }^{6,28}$ We previously showed that this sequential precipitation also takes place in CA-free runs, but at significantly longer periods of time: ${ }^{28} 5 v s .25 \mathrm{~min}$ for stage I-II transition, and 40 vs. $85 \mathrm{~min}$ for stage II-III transition, in CA-inclusive and CA-free systems, respectively.

To gain further insights into the effect of CA on the preand post-nucleation stages of calcium carbonate formation, we performed calcium potentiometric titration tests ${ }^{3}$ (see details in Methods). A $\mathrm{CO}_{2}$-free reactor (i.e., achieved by continuous $\mathrm{N}_{2}$ flushing) was used in order to exclude any enzymatic effect of $\mathrm{CA}$ on the precipitation of calcium carbonate. Fig. 4c shows representative titration curves for the enzyme-free and enzyme-inclusive runs. It was observed that the value of $[\mathrm{Ca}]_{\text {free }}$ was systematically lower than the dosed amount of calcium both for the CA-free and CAinclusive runs. According to Gebauer et al. ${ }^{3}$ this is due to the formation of the so-called stable pre-nucleation clusters (PNCs). Second, after reaching a maximum value following a continuous, nearly linear rise over time, $[\mathrm{Ca}]_{\text {free }}$ rapidly decreased reaching a plateau. The latter reflects the precipitation of a calcium carbonate phase (possibly after a liquid dense precursor), the plateau marking the solubility of the most soluble phase precipitated (i.e., ACC, see below). ${ }^{3}$

The values of IAP at the plateau (Fig. 4c, inset) disclose that the $K_{\mathrm{sp}}$ values of the CA-free and CA-inclusive precipitates were $3.3 \times 10^{-8} \mathrm{M}^{2}$ and $3.8 \times 10^{-8} \mathrm{M}^{2}$, respectively, in good agreement with reported solubility products of ACC. ${ }^{3}$ Finally, XRD analysis of solids collected at the end of the titration experiments yielded $13 \pm 2 \mathrm{wt} \%$ vaterite and $87 \pm 2 \mathrm{wt} \%$ 
calcite in enzyme-free runs, and $66 \pm 5 \mathrm{wt} \%$ vaterite and $34 \pm$ $5 \mathrm{wt} \%$ calcite in enzyme-containing runs.

The onset of precipitation was significantly delayed in the presence of CA, but the slope of the initial linear section of the curves was not much affected by the presence of CA as compared with the control. This shows that CA neither inhibited nor promoted PNC formation by altering cluster formation equilibrium, which would be indicated by an increase or a decrease in the slope, respectively, as compared with the control run. ${ }^{35}$

\section{Ex situ analysis of ACC and crystalline $\mathrm{CaCO}_{3}$ phases}

Fig. 5a shows thermogravimetric/differential scanning calorimetry (TG/DSC) traces of precipitates. ACC formed in the presence of $1.5 \mu \mathrm{M}$ CA and collected from the air-solution interface after $3 \mathrm{~s}$ of $\mathrm{CO}_{2}$ exposure included up to $1 \mathrm{~mol} \mathrm{H}_{2} \mathrm{O}$ per formula unit $\left(\mathrm{CaCO}_{3} \cdot \mathrm{H}_{2} \mathrm{O}\right)$, a value slightly lower than that of ACC formed during stage I in the absence of CA (i.e., 1.5 mol $\left.\mathrm{H}_{2} \mathrm{O}\right) .{ }^{28}$ However, ACC formed in the presence of CA after a longer $\mathrm{CO}_{2}$ exposure time of $5 \mathrm{~min}$ included a slightly higher amount of water (up to $1.7 \mathrm{~mol} \mathrm{H}_{2} \mathrm{O}$ ), in agreement with recent results showing that the degree of ACC hydration increases over time as particles grow in size. ${ }^{36}$ After 10-15 min, however, ACC formed in the presence of CA included only $0.07 \mathrm{~mol}_{2} \mathrm{O}$. A similar trend was previously observed in the case of ACC formed in the absence of CA, where the dissolution of hydrated ACC was followed by the precipitation of poorly hydrated and/or anhydrous ACC. ${ }^{28}$ However, such a solvent-mediated phase transition took place earlier in CAinclusive systems than in the enzyme-free systems (10-15 vs. $30 \mathrm{~min}$, respectively). In all cases, the presence in the DSC traces of an endothermic band at $115-215{ }^{\circ} \mathrm{C}$, followed by an exothermic peak at 330-350 ${ }^{\circ} \mathrm{C}$, confirmed the presence of water and the $T$-induced transition between ACC and crystalline $\mathrm{CaCO}_{3}$, respectively. ${ }^{37}$ XRD analyses confirmed the amorphous nature of these precipitates (Fig. 5b).

Limited CA-incorporation into ACC was demonstrated by the small weight loss $(2.1 \pm 0.8 \mathrm{wt} \%)$ at $250-500{ }^{\circ} \mathrm{C}$, which was not observed in ACC formed in the enzyme-free control (Fig. 5a). Note that oxidative thermal decomposition $(\sim 90$ wt $\%$ loss) of pure CA in air occurs at $220-650{ }^{\circ} \mathrm{C}$ (Fig. S5a $\dagger$ ). FTIR analyses further corroborated the adsorption and/or incorporation of CA into ACC (Fig. 5c). We detected the presence of the characteristic amide I and II bands of CA (Fig. S5b $\dagger$ ) in anhydrous ACC (but not in hydrated ACC), bands which were absent in ACC formed in CA-free runs (Fig. 5c). Similarly, the amide I band was clearly observed in calcite crystals formed after $60 \mathrm{~min}$ of $\mathrm{CO}_{2}$ exposure (Fig. 5c). Moreover, the FTIR spectra of anhydrous ACC and calcite
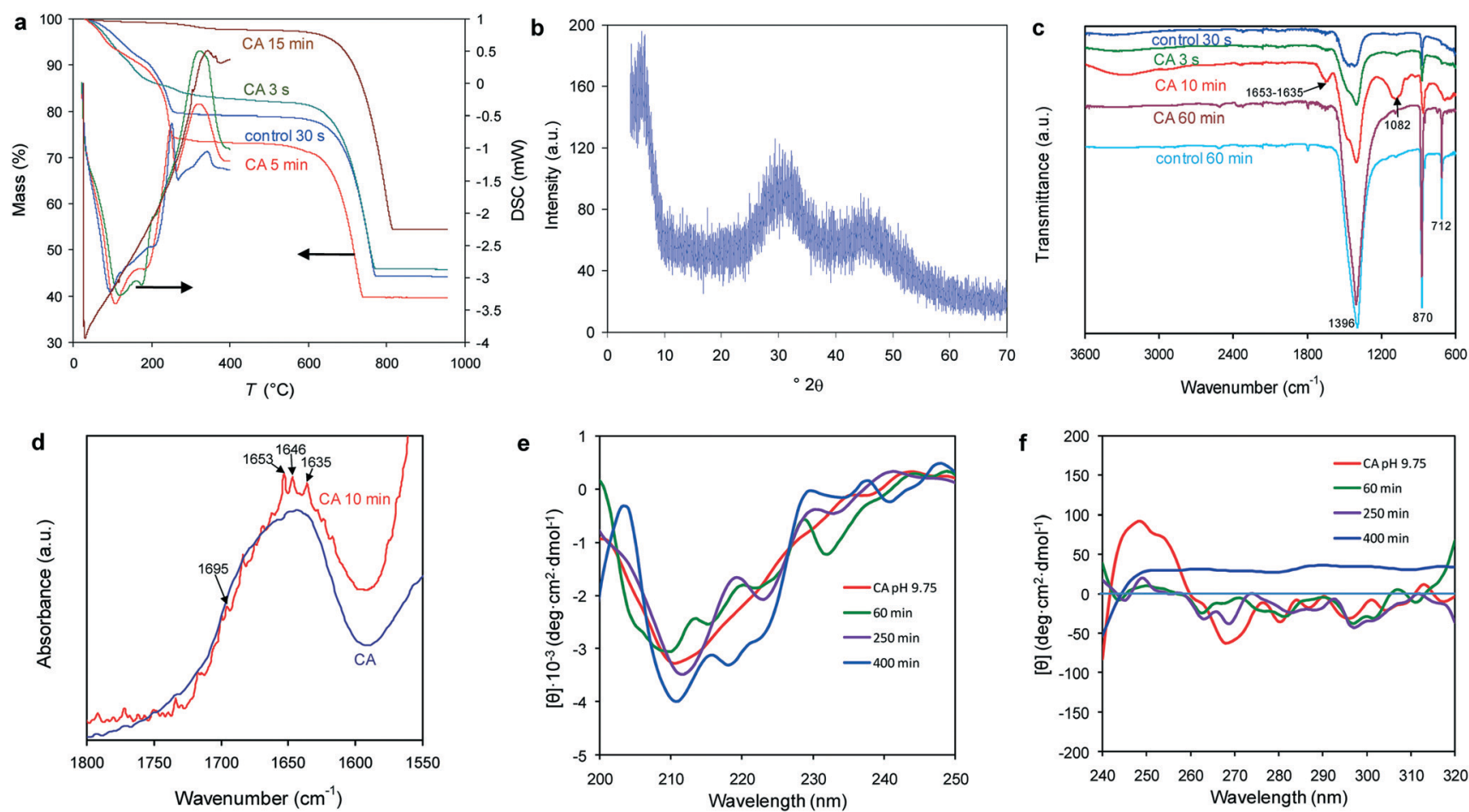

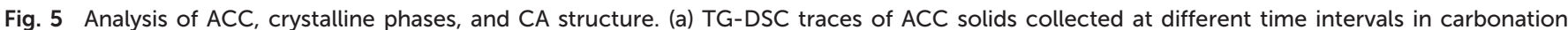

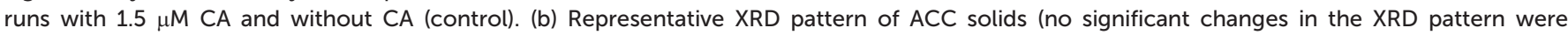

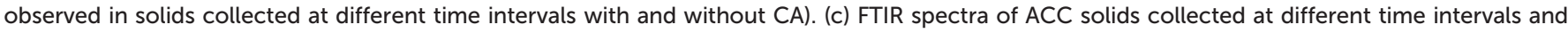

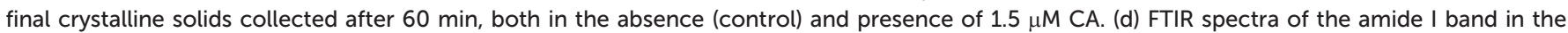

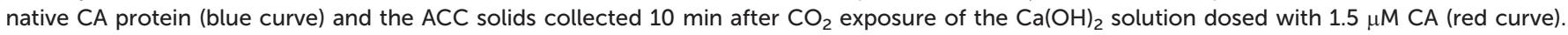

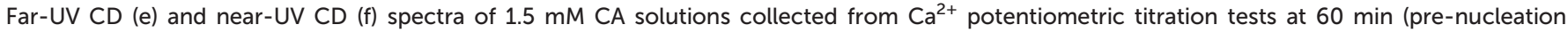
stage), $250 \mathrm{~min}$ (onset of nucleation) and $400 \mathrm{~min}$ (post-nucleation stage), and pure enzyme solution at pH 9.75 (6 h incubation time). 
formed in the presence of CA showed that the amide I band had an increased contribution of $\beta$-sheet structure (bands at 1635 and $1695 \mathrm{~cm}^{-1}$ ) as compared with the pure (native) protein (Fig. 5d).

\section{Evolution of CA structure and enzymatic activity}

To evaluate whether the secondary and tertiary structures of the enzyme, as well as its catalytic activity, were possibly altered during $\mathrm{CaCO}_{3}$ precipitation, and what role the $\mathrm{pH}$ (i.e., ranging from $\sim 12$ down to $\sim 8$ in droplet experiments or 9.75 in calcium potentiometric titration tests) and the presence of calcium and carbonate ions played in such possible structural changes, we performed circular dichroism (CD) analysis of protein solutions after 60 min incubation time (corresponding to stage III in $200 \mu \mathrm{L}$ droplet experiments). Far-UV CD results showed that the secondary structure of the enzyme was not significantly affected by $\mathrm{pH}$

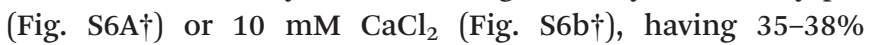
antiparallel $\beta$-strand, $12-15 \% \quad \beta$-turn, 4-6\% $\alpha$-helix and $42-$ $46 \%$ random coil. In contrast, carbonate ions at $\mathrm{pH} 12$ led to the emergence of a strong band at $205 \mathrm{~nm}$, corresponding to $60 \%$ random coil (Fig. S6c $\dagger$ ). ${ }^{38}$ The latter shows that carbonate ions at a high $\mathrm{pH}$ fostered the unfolding of this globular protein. For the specific case of $\mathrm{pH} 9.75$, the negative mean residue ellipticity was slightly reduced in the presence of carbonate and calcium ions as compared to the pure enzyme solution (Fig. S6d $\uparrow$ ). Near-UV CD results showed that $\mathrm{pH}$ alone did not significantly affect the tertiary structure of CA (Fig. S6e $\dagger$ ). In contrast, the presence of $\mathrm{Ca}^{2+}$ (Fig. S6f $\dagger$ ) as well as $\mathrm{CO}_{3}{ }^{2-}$ (Fig. S6g $\dagger$ ), especially at $\mathrm{pH} \geq$ 9.75 (Fig. $\mathrm{S} 6 \mathrm{H} \dagger$ ), led to $\mathrm{CA}$ unfolding and loss of the tertiary structure. This was reflected by the reduction in mean residue ellipticity due to solvent-exposure of the side chains of aromatic (hydrophobic) amino acid residues that are buried within the protein prior to unfolding. ${ }^{38}$ In the case of the precipitation tests involving calcium potentiometric titration ( $\mathrm{pH}$ 9.75), far-UV CD showed an increase in the $\beta$-sheet component over the course of precipitation (up to $51 \%$ antiparallel $\beta$-strand, 13\% $\beta$-turn, 1\% $\alpha$-helix and 35\% random coil, after $400 \mathrm{~min}$ ) (Fig. 5e). In parallel, the tertiary structure was partially lost as shown by the near-UV CD spectra (Fig. 5f). The significant (yet not fully complete) loss of CA enzymatic activity was confirmed by the $p$-nitrophenyl acetate esterase assay of solution aliquots collected during $\mathrm{CaCO}_{3}$ precipitation in titration tests showing a $50 \pm 5 \%$ and $83 \pm 5 \%$ decrease in esterase activity at $60 \mathrm{~min}$ (prenucleation stage) and $400 \mathrm{~min}$ (post-nucleation stage), respectively.

\section{TEM analysis of precipitates}

TEM observations disclosed that a few seconds after atmospheric $\mathrm{CO}_{2}$ exposure in $\mathrm{CA}$-inclusive droplet runs $(200 \mu \mathrm{L})$, "emulsion-like", low contrast precipitates made up of scattered shapeless Ca-rich particles (according to EDS microanalysis) a few $\mathrm{nm}$ in size and showing connecting necks were present (Fig. 6a). These features are characteristic of dense liquid precursors ${ }^{9,39}$ whose formation is consistent with the high supersaturation reached at the onset of precipitation during stage I (Fig. 4b), which should favor binodal $^{9}$ or spinodal decomposition, ${ }^{40,41}$ as we have previously shown for the case of CA-free systems. ${ }^{28}$ The fact that similar structures are observed using cryo-TEM during the very early stages of precipitation, ${ }^{39}$ but are not observed after this initial precipitation stage using cryo-TEM or, in our case, using TEM, confirms that they are not an artifact of our sample preparation procedure for TEM analysis (ethanol quenching and subsequent drying, or freeze-drying). Apparently, the formation of a dense liquid precursor appears to be the rule, not the exception, during calcium carbonate precipitation at high supersaturation. ${ }^{9}$

After $\sim 3-5$ min of $\mathrm{CO}_{2}$ exposure, aggregates of sphericalshaped ACC particles (100-300 $\mathrm{nm}$ in diameter), whose amorphous nature was confirmed by the diffuse haloes in SAED patterns (Fig. 6b), formed during stage I. Exposure to a focused e-beam for $30 \mathrm{~s}$ led to massive shrinking of such ACC spheres due to $\mathrm{H}_{2} \mathrm{O}$ loss, and the formation of nonoriented $\mathrm{CaO}$ crystals showing Debye rings in the SAED pattern (Fig. 6b, inset). Such a behavior under focused e-beam irradiation is standard for hydrated ACC. ${ }^{28,36}$ In samples collected after 5-10 $\mathrm{min}$ of $\mathrm{CO}_{2}$ exposure, low e-absorbing circular structures including higher contrast ACC nanoparticles were observed (Fig. 6c). Such features might suggest the formation of a coacervate ${ }^{7}$ or a PILP phase. ${ }^{4}$ However, coacervate and PILP droplets are typically micrometer-sized and include calcium (and carbonate) ions. ${ }^{4}$ The relatively small size (200-600 $\mathrm{nm}$ in diameter) and the lack of Ca (EDS microanalysis) in these structures suggest that they were pure protein aggregates. Likely, they correspond to a dense liquid protein precursor, which is known to precede protein crystallization, ${ }^{42}$ and could entrap ACC nanoparticles.

After 15-30 min of $\mathrm{CO}_{2}$ exposure (i.e., stage II), isolated or interconnected planar (sheet-like) and fibrous structures resembling a hydrogel phase were observed using bright-field TEM and Z-contrast high-angle annular dark field (HAADF) imaging (Fig. 6d-h and S7 $\dagger$ ). They were apparently amorphous (see the SAED pattern in Fig. 6h). Focused e-beam irradiation for 30-90 $\mathrm{s}$ led to their conversion into randomly oriented graphite (Fig. 6h). EDS microanalysis showed that the structures included $\mathrm{C}$ and $\mathrm{N}$ but negligible $\mathrm{Ca}$ (Fig. S8†). Altogether, these results confirm that these structures corresponded to CA and suggest that Ca was not complexed by them to a significant extent. Note that drying (in an oven at $60{ }^{\circ} \mathrm{C}$ and/or in air at room $T$ after ethanol quenching) of aqueous solutions of the pure protein did not result in such planar and fibrous structures but in shapeless low-contrast protein aggregates (Fig. S9†). The CA structures formed in our droplet experiments were either naked (Fig. 6e, $\mathrm{h}$ and $\mathrm{S} 7 \mathrm{a}-\mathrm{c} \dagger$ ) or covered by/attached to anhydrous ACC (Fig. 6d, f, g, and S7d-f $\dagger$ ). The latter implies that these structures precede and enable anhydrous ACC heterogeneous 

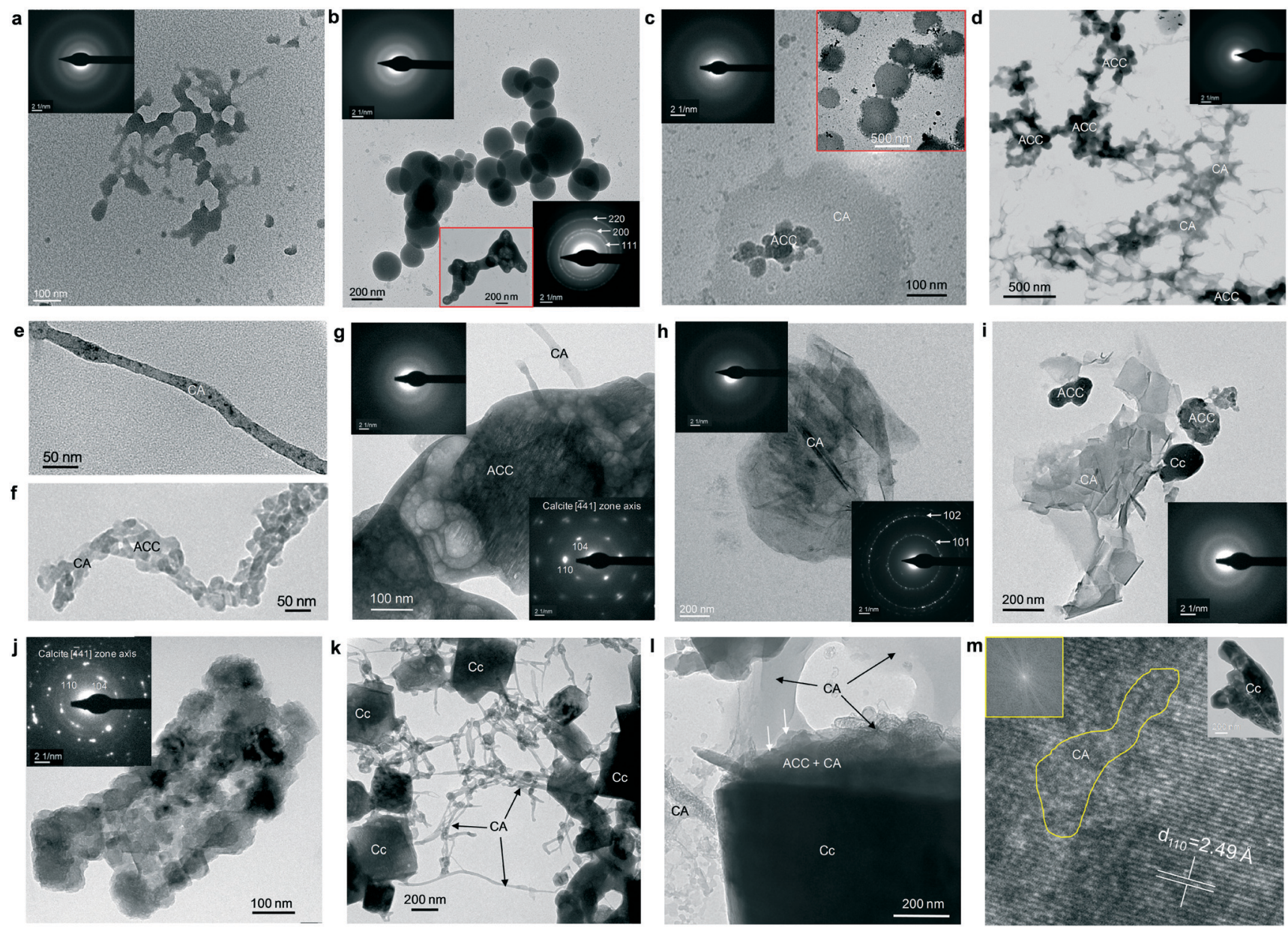

Fig. 6 Time-resolved TEM analysis of precipitates formed in the presence of $1.5 \mu \mathrm{M} \mathrm{CA}$. (a) Emulsion-like nanostructure formed right after exposure of the $\mathrm{Ca}(\mathrm{OH})_{2}$ solution to atmospheric $\mathrm{CO}_{2}$ (SAED pattern in the inset). (b) Hydrated ACC formed during stage I (3 min $\mathrm{CO}_{2}$ exposure). The upper-left and lower-right insets show the SAED patterns of the particles before and after focused e-beam exposure (30 s), respectively, leading to dehydration-induced shrinking (inset marked by the red square) and formation of non-oriented CaO producing Debye rings ( $h k l$ values are indicated). (c) Aggregates of CA including ACC nanoparticles formed following 5-10 min $\mathrm{CO}_{2}$ exposure (stage II). Low magnification of CA aggregates in the upper-right inset and the SAED pattern of the (amorphous) CA structure in the upper-left inset. (d) Z-contrast HAADF image of (dark) ACC aggregates (SAED pattern in the inset) associated with (light) CA fibrils and sheets forming a hydrogel-like structure after 15 min of $\mathrm{CO}_{2}$ exposure. Details of (e) non-mineralized and (f) ACC-mineralized CA fibrils. (g) Anhydrous ACC aggregates (SAED pattern in the upper-left inset) present after 15-30 min of $\mathrm{CO}_{2}$ exposure (stage II) and associated with CA fibrils. Focused e-beam exposure (30 s) transforms ACC with negligible shrinking into a calcite pseudomorph showing a single-crystal SAED pattern (lower-right inset). (h) Amorphous CA sheets present during stage II (SAED pattern in the upper-left inset) that upon e-beam irradiation transform into randomly oriented graphite (spotted Debye rings; lower-right inset). (i) CA sheets and fibrils associated with ACC and newly-formed calcite (Cc) (stage III). SAED pattern of the CA structures in the inset. (j) Calcite nanocrystals forming a mesostructure during stage III (SAED pattern in the inset). The low e-absorbing areas between nanoparticles are pores and/or entrapped CA. (k) Calcite crystals associated with CA sheets and fibrils (stage III). (l) Details of a calcite crystal surrounded by CA sheets, which include hemispherical -ACC- nanostructures (white arrows). (m) HRTEM lattice image of calcite (low magnification image in the upper-right inset) showing a non-crystalline area (FFT in the upper-left inset) within its interior (marked by the yellow curve). This area corresponds to occluded CA.

nucleation. Anhydrous ACC formed in the presence of CA during stage II was unambiguously identified because focused e-beam irradiation for $30 \mathrm{~s}$ induced no shrinking (Fig. $6 \mathrm{~g}$ and $\mathrm{S} 10 \dagger$ ) and led to the formation of oriented calcite (SAED pattern in the inset of Fig. $6 \mathrm{~g}, \mathrm{~S} 10 \mathrm{~b}$ and S10d $\dagger$ ). Such distinctive features of anhydrous ACC were previously observed in enzyme-free systems. ${ }^{28}$

After $\sim 45-60 \mathrm{~min}$ of $\mathrm{CO}_{2}$ exposure, that is during stage III, anhydrous ACC and calcite crystals were observed to be attached to the CA structures (Fig. 6i-l). A close inspection of the initial calcite precipitates revealed that they were made up of nanocrystals with a preferred crystallographic orientation, thereby showing nearly single-crystal SAED patterns with spots displaying $\sim 8^{\circ}$ angular spreading (Fig. 6j). These features strongly resemble those of a mesocrystal structure., ${ }^{5,14}$ Over time (up to $60 \mathrm{~min}$ ) the calcite structures were more compact and diffracted as perfect single crystals, likely due to recrystallization and fusion of the individual crystallites making up the mesocrystal structure (Fig. $6 \mathrm{k}$ and $\mathrm{l}$ ). HRTEM lattice images of calcite crystals 
showed low e-absorbing amorphous areas (Fig. 6m), which we interpret as occluded proteins. This is demonstrated by the fact that the areas remained amorphous following prolonged HRTEM imaging, whereas the rest of the crystal converted into $\mathrm{CaO}$ nanocrystals due to beam damage. If the amorphous areas were ACC, conversion into $\mathrm{CaO}$ should have occurred eventually. ${ }^{28}$

\section{Discussion}

Our results show that CA has profound and manifold effects on the formation and evolution of calcium carbonate phases. Two main types of effects are observed, depending on whether CA acts as a monomer in solution (with a native structure) or as insoluble supramolecular assemblies.

Regarding the first set of effects, our results show that despite the high initial $\mathrm{pH}$ in our system ( $\mathrm{pH}$ 12.4) the enzyme displays a high catalytic activity during the early stages of calcium carbonate precipitation. In particular, our results show that CA not only accelerates ACC precipitation, but also the transformation of hydrated into anhydrous ACC, and later on, into calcite (and minor vaterite), as compared to CA-free systems. ${ }^{28} \mathrm{CA}$ initially accelerates $\mathrm{CO}_{2}$ hydration providing $\mathrm{HCO}_{3}{ }^{-}$ions to the system, but it also catalyzes the backward reaction $\mathrm{HCO}_{3}{ }^{-}+\mathrm{H}^{+}=\mathrm{CO}_{2}+\mathrm{H}_{2} \mathrm{O}$, or more precisely $\mathrm{HCO}_{3}{ }^{-}=\mathrm{CO}_{2}+\mathrm{OH}^{-}$(due to the alkaline $\mathrm{pH}$ in our system). These reactions are the rate-determining step(s) of the overall precipitation reaction $\mathrm{Ca}^{2+}+2 \mathrm{HCO}_{3}{ }^{-}=\mathrm{CaCO}_{3}+$ $\mathrm{H}^{+}+\mathrm{HCO}_{3}{ }^{-}=\mathrm{CaCO}_{3}+\mathrm{CO}_{2}+\mathrm{H}_{2} \mathrm{O} .{ }^{2,30}$ Hence, CA can not only accelerate the initial precipitation of ACC, but also its conversion into calcite via the dissolution reaction $\mathrm{CaCO}_{3}+$ $\mathrm{CO}_{2}+\mathrm{H}_{2} \mathrm{O}=\mathrm{Ca}^{2+}+2 \mathrm{HCO}_{3}{ }^{-}$, which is rate-determining. ${ }^{16}$ These results may help to answer the long standing question of how organisms can mobilize or transform ACC into crystalline phases in a fast way. ${ }^{8}$

Note that because in our titration tests the system was $\mathrm{CO}_{2}$-free, no CA-catalyzed hydration of $\mathrm{CO}_{2}$ and the resulting increase in the amount of DIC and the system's supersaturation (and the acceleration of precipitation) were expected. In this case, CA in solution acted as a strong nucleation inhibitor, likely because its interaction with PNCs hampered their aggregation to form a condensed phase (e.g., a dense liquid precursor and/or ACC). A similar nucleation inhibition behavior has been reported for different organic additives, including some amino acids (e.g., Asp and Glu) ${ }^{35}$ and several matrix proteins from mollusk shells, ${ }^{43}$ and echinoderm spicules. ${ }^{44}$ Importantly, the observed nucleation inhibition was not related to binding of $\mathrm{Ca}^{2+}$ ions by the functional groups of amino acid size-chains in the protein, an effect that reduces calcium activity and the system's supersaturation. Such an effect is easily disclosed during the titration experiments by a delay in the onset of $[\mathrm{Ca}]_{\text {free }}$ rise,$^{35}$ which was not observed here. In this case, nucleation inhibition is most likely the result of stabilization of PNCs, similar to colloid stabilization, as reported for other calcium carbonate systems. ${ }^{35}$ Altogether, our results show that CA strongly interacts with pre-nucleation ion associates, but its nucleation inhibition effect is outpaced by its catalytic role in systems in contact with $\mathrm{CO}_{2}$.

The higher vaterite content in CA-inclusive titration runs as compared with control runs can be explained by considering the solubility products of ACC formed in these two systems. The solubility products of ACC in the enzymefree and enzyme-inclusive systems match those of protocalcite and protovaterite ACC, respectively. According to Gebauer et al., ${ }^{3}$ these precursors would respectively favor the formation of calcite (control run) and vaterite (CA-inclusive run), as it is observed here. Note that in contrast to in situ $\mathrm{OM}$ and XRD results showing calcite as the main crystalline polymorph upon carbonation of $\mathrm{Ca}(\mathrm{OH})_{2}$ solution droplets both in the absence and presence of CA, the abundant vaterite formed in the presence of CA in titration experiments shows that CA does not seem to play a role in polymorph selection. This is important, because it suggests that the concerted action of CA with other matrix proteins is necessary for polymorph selection during calcium carbonate biomineralization.

Another interesting effect brought about by the presence of $\mathrm{CA}$ is the formation of convoluted iridescent patterns made up of ACC nanoparticles at the air-solution interface. Such patterns typically result from surface tension fluctuations and associated Marangoni flow, leading to the self-organization of nanoparticles at the air-solution interface. ${ }^{45}$ In our case the reduction in surface tension is associated with adsorption of CA -an amphiphilic globular protein- ${ }^{18}$ at the air-solution interface, as demonstrated for this protein ${ }^{46}$ as well as other globular proteins. ${ }^{47}$

Our AFM results show that CA in solution strongly interacts with the monomolecular growth steps of (10.4) calcite surfaces and leads to significant morphology changes. Similar habit modifications have been observed both at the macro- and nanoscale -using AFM- in the case of biogenic calcite (e.g., otoconia) ${ }^{48}$ as well as abiotic calcite precipitated in the presence of mollusk shell acidic proteins, ${ }^{34,49,50}$ peptides (e.g., poly-Asp), ${ }^{51}$ and amino acids, particularly acidic ones such as Glu and Asp. ${ }^{50}$ Asp and Glu are the two most abundant amino acid residues in $\alpha$-CA, ${ }^{18}$ and their side-chain carboxylic groups must be deprotonated at our working alkaline $\mathrm{pH}(\mathrm{CA} \mathrm{pI}=5.9) .{ }^{18}$ Such acidic amino acid residues, likely in concerted action with polar amino acid residues present in CA, would enable the adsorption of this protein onto calcite (acute) steps, as shown by molecular modeling of $\operatorname{Asp}_{n}$ ( $n=1$ to 5 ) peptides binding to calcite steps and neighboring terraces. ${ }^{51}$ The preferential adsorption of CA at the acute steps is possibly due to stereochemical constraints ${ }^{52}$ or energetic effects associated with surface dehydration. ${ }^{51}$ Organic additives (e.g., acidic macromolecules) typically act as nucleation and growth inhibitors, ${ }^{53}$ reducing the spreading rate of steps due to their pinning, and leading to their rounding and bunching, ${ }^{51,52}$ as shown here for the case of the acute steps. The observed CA-induced acceleration of obtuse steps has been previously observed in the presence of mollusk 
shell matrix proteins, ${ }^{34,49}$ nacre-associated polypeptides, ${ }^{50}$ and some peptides. ${ }^{51}$ Although the mechanism(s) by which proteins and (poly)peptides accelerate step kinetics is not well-constrained, following Fu et $a .^{34}$ we suggest that a likely contributor is surfaction, resulting in changes in the thermodynamics and kinetics of calcium and carbonate ion attachment at steps. Because CA is amphiphilic and upon adsorption can reduce the interfacial energy of liquid-gas or liquid-solid interfaces, ${ }^{47}$ this protein could therefore play a surfactant role during calcite crystal growth. Altogether, the two step-specific kinetic effects of CA in solution (acceleration -obtuse-, and deceleration -acute-) led to important changes in growth kinetics, resulting in the observed macroscopic habit changes which are a landmark of calcite crystals precipitated biotically and biomimetically in the presence of a range of (bio)macromolecules. ${ }^{5}$

The observed nanogranular features of calcite crystals formed in the presence of CA in our droplet experiments (high supersaturation), which are present in most carbonate biominerals, ${ }^{6,11,33}$ can emerge following non-classical calcite growth via attachment of ACC nanoparticles in the presence of soluble organics. ${ }^{37}$ However, the formation of calcite (and minor vaterite) in our droplet experiments involved the prior dissolution of ACC forming a precipitate-free area around the newly formed crystals. This suggests that calcite nucleates and grows via a classical mechanism (i.e., ion-by-ion incorporation), which would appear incompatible with the observed nanogranular features. Interestingly, ACC nanoparticles in our experiments were still present (dispersed in the bulk droplet solution, as observed using OM) when calcite was growing, and could therefore undergo Brownian motion and attach onto such calcite crystal seeds contributing to their grow via a non-classical aggregationbased mechanism. ${ }^{1,33,37}$ In support of this latter growth mechanism, cryo-TEM analyses have shown the coexistence of ACC nanoparticles in solution that contributed to the growth of crystalline $\mathrm{CaCO}_{3}$ (vaterite) formed under a selfassembled monolayer. ${ }^{1}$ Moreover, recent experimental findings show that the initial calcite seeds grown at a high supersaturation in the presence of soluble additives systematically were perfect rhombohedra (i.e., classical crystallization event) and further growth led to the nanogranular features and altered habit. ${ }^{54}$ We therefore propose that after the initial classical nucleation and growth of calcite after ACC dissolution, non-classical growth via attachment of ACC nanoparticles occurred resulting in crystalline structures displaying the landmark features of biotic and biomimetic mesocrystals, such as the observed nanogranular structure and the single-crystal SAED pattern with a relatively small angular spreading. ${ }^{12-14}$ Such structures can retain the original ACC nanogranular structure imprinted in the final crystalline polymorph, ${ }^{6,11}$ when the amorphousto-crystalline transformation takes place via a pseudomorphic interface-coupled dissolution-precipitation mechanism, as we have demonstrated for the non-classical growth of calcite following ACC nanoparticle attachment in the presence of (poly)acrylic acid. ${ }^{37}$ In the present case, CA molecules, either present in solution or released after dissolution of ACC attached to calcite seeds, could in turn affect the growth (kinetics and morphology) of calcite mesostructures via stepspecific interactions in a similar way to that in our in situ AFM experiments.

The second set of effects of CA was associated with the structural changes undergone by this protein. Our FTIR and CD analyses in combination with ESEM-EDS, TEM-SAED and HAADF-EDS results show that the (partial) unfolding and loss of the native globular structure of CA favored aggregation into supramolecular assemblies such as fibers and film-like structures that organized into hydrogel-like aggregates during stages II and III. These structures displayed an extended $\beta$-sheet structure, and their unfolding was facilitated by both $\mathrm{Ca}^{2+}$ and $\mathrm{CO}_{3}{ }^{2-}$ ions at the alkaline $\mathrm{pH}(\sim 8-12)$ of our precipitation experiments (i.e., CD results). Previous studies have shown that CA unfolding and denaturation leads to a "molten globule" state, where the secondary structure is not much modified, but the protein has lost its catalytic activity. Subsequently, CA oligomerizes forming an intermolecular $\beta$-structure. Such oligomers are ultimately assembled into a gel-like structure. ${ }^{55}$ Formation of similar (amyloid) fibrils, sheaths and hydrogel-like structures has been observed during in vitro biomineralization of $\mathrm{CaCO}_{3}$ in the presence of nacre $^{43}$ and sea urchin spicule matrix proteins. ${ }^{13,44}$ Such supramolecular protein structures, whose self-assembly appears to be induced/facilitated by $\mathrm{Ca}^{2+}$ ions, have been shown to direct $\mathrm{CaCO}_{3}$ precipitation via dense liquid and amorphous solid precursor phases, ${ }^{13}$ and induce the oriented heterogeneous nucleation of crystalline calcium carbonate phases, especially in the case of Asp- and Glu-rich matrix proteins. $^{5,53}$ Other proteins, such as silk fibroin, have also been shown to undergo structural changes and direct the growth of biomimetic calcium carbonate crystalline structures formed via ACC precursor nanophases. ${ }^{56,57}$ In our case, partial unfolding and self-assembly of CA is not only induced by $\mathrm{Ca}^{2+}$ but also by $\mathrm{CO}_{3}{ }^{2-}$ ions. This is highly relevant because CA catalyzes the formation of bicarbonate ions that readily deprotonate at alkaline $\mathrm{pH}$ forming carbonate ions. The formation of the latter anions would ultimately trigger the loss of the tertiary structure of CA and, hence, its catalytic activity as demonstrated by our CD and esterase test results. Such a negative feedback mechanism would first help jump-start $\mathrm{CaCO}_{3}$ mineralization and subsequently contribute to the arrest of this process, offering a simple mechanism for organisms to control $\mathrm{CaCO}_{3}$ biomineralization. Otherwise, if $\mathrm{CA}$ endlessly remained catalytically active once secreted, it would be difficult for an organism to stop the biomineralization process. The observed loss of $\mathrm{CA}$ catalytic activity under alkaline $\mathrm{CO}_{3}{ }^{2-}$-rich conditions also helps to explain the reported loss in process efficiency during CA-catalyzed biomimetic $\mathrm{CO}_{2}$ mineral sequestration. ${ }^{29}$

Our TEM-HAADF observations show that in the CAinclusive system anhydrous ACC nucleated on the protein 
fibrils/films and hydrogel-like structures that appeared during stage II. Similarly, upon anhydrous ACC conversion into calcite via dissolution-precipitation, the close spatial association between the protein film/fiber structures and calcite demonstrates that CA also plays a key role as an organic template for the heterogeneous nucleation of this crystalline phase and facilitates the occlusion of the protein within the crystals, as shown by our TG/DSC, FTIR and HRTEM results. It is important to underline that despite the clear nucleation inhibition power of CA monomers in the bulk solution, organics with a strong nucleation inhibition effect in bulk solution in most cases are strong crystallization promoters when adsorbed at an interface or when they form supramolecular assemblies (e.g., extended $\beta$-sheet protein or polypeptide films), as in the latter cases they can induce and/ or facilitate the heterogeneous template-directed nucleation of a solid phase. ${ }^{4,53}$

Despite the observed structural changes, a sufficient amount of catalytically-active CA monomers must remain in solution during the transition from stage II to stage III, in order to speed up the amorphous to crystalline transition. This is consistent with our esterase assay results demonstrating that despite the significant reduction observed, some enzyme activity remains even after precipitation of calcite (i.e., after $400 \mathrm{~min}$ ). Note that the kinetics of protein oligomerization and self-assembly are strongly dependent on denaturation conditions, and can take minutes to days. ${ }^{58}$ It is expected that eventually such a residual activity will be fully lost contributing to the arrest of $\mathrm{CaCO}_{3}$ (bio)mineralization.

In summary, our results show that CA, an enzyme which is systematically present in organisms producing calcium carbonate skeletons and is currently used for biomimetic $\mathrm{CO}_{2}$ mineral sequestration, not only catalyzes the formation of the reactive precursors required for mineralization and accelerates the precipitation of ACC and its conversion into calcite (and minor vaterite), but also plays a critical role in the evolution of calcite crystals' (nano)structure and morphology, interacting with and being incorporated into the newly formed $\mathrm{CaCO}_{3}$ precipitates. To our knowledge the latter structural role of CA, similar to that of other matrix proteins of a range of biominerals, ${ }^{4,5,13,43}$ has not been reported before, and may have far-reaching implications in our understanding of the biomineralization of calcium carbonates. The observed structural and conformational changes undergone by CA in the presence of $\mathrm{Ca}^{2+}$ and $\mathrm{CO}_{3}{ }^{2-}$ ions in solutions, resulting in partial unfolding, oligomerization, supramolecular selfassembly, and formation of amyloid-like fibrils, films, and hydrogel-like structures, enable the templated precipitation of amorphous and crystalline calcium carbonate with a mesostructure similar to that of several biominerals. ${ }^{12,13}$ Moreover, these structural changes result in the loss of the native tertiary structure of this globular protein and hence its catalytic activity. The latter can act as a negative control to help arrest $\mathrm{CaCO}_{3}$ biomineralization and is detrimental to CAcatalyzed $\mathrm{CO}_{2}$ mineral sequestration. Although our results are based on in vitro biomimetic mineralization tests, and would require in vivo confirmation, they give support to the idea that CA is one of the key components of Nature's minimal biomineralization toolkit. Regarding the relevance of our results in the biomineralization of calcium carbonates, we want to stress that the selected CA concentrations (i.e., 6-45 ppm) are in the same range as those reported for tissues involved in calcium carbonate biomineralization, such as the mantle of Mediterranean mussel Mytilus galloprovincialis, which includes $\sim 25$ ppm CA. ${ }^{23}$ Note also that although variability in their full amino acid sequence is observed, $\alpha$-CAs of organisms forming calcium carbonate biominerals, as well as human and bovine $\alpha$-CAII (i.e., the enzyme used in our experiments, see Methods), show conserved domains and significant homology in specific amino acid sequences and display the same structure in the catalytic site. ${ }^{22,59-62}$ Moreover, enzymatic activity tests have shown that the rates of $\mathrm{CO}_{2}$ hydration by CA present in corals and mollusks are of the same order of magnitude as those of bovine CA used here. ${ }^{21,24}$ In lieu of the above, we are thus confident that the results obtained here using bovine CA are of relevance for calcium carbonate biomineralization in nature. The gained knowledge is not only relevant for a better understanding of biomineralization processes, but also offers new possibilities for the CA-assisted development of novel biomimetic $\mathrm{CaCO}_{3}$ functional materials, CA-enhanced formation and transformation of ACC nanoparticles for biomedical (e.g., drug delivery) or cultural heritage conservation (e.g., stone consolidants) applications, and for improved biomimetic $\mathrm{CO}_{2}$ mineral sequestration via CAcatalyzed carbonation. Considering that CA is also involved in bone biomineralization and remodeling, as well as in a range of osteopathologies, we expect that our results will also bear relevance for such calcium phosphate-based systems.

\section{Methods}

\section{Solutions and crystallization of $\mathrm{CaCO}_{3}$}

Saturated $\mathrm{Ca}(\mathrm{OH})_{2}$ solutions $(\sim 20 \mathrm{mM})$ were prepared at room $T$ by dissolving $\mathrm{Ca}(\mathrm{OH})_{2}$ crystals in MilliQ water (conductivity $<18 \mathrm{mS}$ ) under vigorous stirring for $24 \mathrm{~h}$ in a sealed plastic bottle with no head space. The carbonic anhydrase (CA) enzyme from bovine erythrocytes ( $\alpha$-CAII enzyme; E.C. 4.2.1.1; Sigma-Aldrich) was added to the $\mathrm{Ca}(\mathrm{OH})_{2}$ solutions prior to carbonation tests to obtain a wide range of enzyme concentrations $(0.0,0.2,0.4,0.6,0.8$ and 1.5 $\mu \mathrm{M})$. Note, however, that our previous results show that CA effects on carbonation kinetics are more evident for enzyme concentration $\geq 0.6 \mu \mathrm{M}^{59}$ This is why most experiments described here were performed using a $1.5 \mu \mathrm{M}$ CA concentration.

For carbonation tests, solution droplets ( 5 to $200 \mu \mathrm{L}$ ) with and without the enzyme were placed on different supports (see below) and exposed to atmospheric $\mathrm{CO}_{2}$ at room $T$. Droplets subjected to different carbonation times were quenched in ethanol (puriss. 99.8\%, PanReac) or freeze-dried (plunge freezing in liquid $\mathrm{N}_{2}$, and subsequent vacuum drying 
at $-50{ }^{\circ} \mathrm{C}$ using Telstar Cryodos equipment) prior to analysis using TEM (see below). Note that such quenching procedures, which are routinely used during the study of ACC, reportedly produce no detectable artifact or dryinginduced textural/structural transformations. ${ }^{28}$ Ion selective microelectrodes (ISE) were used for on-line measurement of pH (micro combination electrode mod. PHR-146B, Lazar Laboratories) and calcium activity, [Ca] (micro-ISE mod. LIS146CACM with microdouble junction reference electrode mod. DDM-146, Lazar laboratories) during carbonation in $200 \mu \mathrm{l}$ droplets. Microelectrodes were calibrated using standard $\mathrm{pH}$ buffered solutions and $\mathrm{CaCl}_{2}$ solutions of known concentration ( 0.01 to $100 \mathrm{mM})$. The concentration of total dissolved $\mathrm{CO}_{2}$ (i.e., total dissolved inorganic carbon) was measured using a $\mathrm{CO}_{2}$-selective electrode (Thermo Scientific, mod. 9502BNWP) following the protocol outlined elsewhere. $^{28}$ A minimum of three replicas of each measurement/test were performed.

Additional carbonation experiments were performed using a $T$-controlled batch reactor $(7 \mathrm{~cm}$ internal diameter crystallization dishes, filled with $150 \mathrm{~mL} \mathrm{Ca(OH})_{2}$ saturated solution). Carbonation took place upon air exposure at $20{ }^{\circ} \mathrm{C}$ under continuous stirring (150 rpm). Measurements of $\mathrm{pH}$ and $[\mathrm{Ca}]$ were performed as in the case of droplets (see above). Following precipitation, suspension aliquots (ca. 5 $\mathrm{mL}$ ) were collected at different reaction times and vacuum filtered or freeze-dried (as described above) prior to storage under dry conditions. Batch reactor tests enabled us to collect sufficient amounts of precipitate for ex situ analyses (see below). As shown previously for precipitation in CA-free solutions, the only effect of the lower (air-exposed) surface/ volume ratio of crystallization dishes as compared with droplets was a longer waiting time (no changes in the precipitation sequence, phase composition or habit were detected). ${ }^{28}$

\section{In situ polarized light microscopy and $\mu$-Raman analyses}

Droplets $(10 \mu \mathrm{L})$ of $\mathrm{Ca}(\mathrm{OH})_{2}$ saturated solution with and without CA were deposited on an ultraclean [100]-oriented silicon wafer (Virginia Semiconductor Inc.) and exposed to air at room $T$ inside the chamber of a Jasco NRS-5100 $\mu$-Raman spectrometer equipped with a CCD detector (DV420-OE, Peltier-cooled, $1024 \times 255$ pixel UV-NIR range), an integrated Olympus optical microscope, and a highresolution built-in CMOS camera. Microscopic observations were performed simultaneously with micro-Raman spectra acquisition (excitation with $4 \mathrm{~mW}$-power diode laser operated at $532 \mathrm{~nm}$ or $785 \mathrm{~nm}$; frequency range $100-3900 \mathrm{~cm}^{-1}$; spectral resolution of $4 \mathrm{~cm}^{-1}$ ). Averaged values of five spectra (10 s acquisition time) for each analyzed spot are reported here. Calibration was performed using the $520.5 \mathrm{~cm}^{-1}$ band of the silicon wafer.

Polarized light microscopy (Jenapol Zeiss, equipped with a digital camera) was used to study the crystallinity and morphology of solid phases, as well as their evolution during carbonation in the absence and presence of CA. Sample and carbonation conditions were similar to those prevailing in micro-Raman experiments, with the difference that in the former case solution droplets $(10-200 \mu \mathrm{L})$ were placed either on Si wafers (observed under reflected light) or on glass slides (observed under transmitted light).

\section{In situ XRD}

Droplets of $\mathrm{Ca}(\mathrm{OH})_{2}$ saturated solution $(200 \mu \mathrm{L})$ with and without CA were placed onto a zero-background Si sample holder inside the chamber of a PANalytical X'Pert Pro X-ray diffractometer. Exposure to air, at room $T$, resulted in carbonation at the solution/air interface. Real-time precipitation of calcium carbonate was monitored with continuous acquisition of XRD patterns with $\mathrm{Cu} K \alpha$ radiation $(\lambda=1.5405 \AA)$, in the 10 to $50^{\circ} 2 \theta$ range at a scanning rate of $0.11^{\circ} 2 \theta \mathrm{s}^{-1}$. This scanning speed ( $\sim 6 \mathrm{~min}$ per diffractogram) reliably enabled the detection of the newly-formed crystalline phases. The time evolution of the amount of ACC and calcite was quantified by measuring the integral intensity of the main 104 Bragg peak of calcite and the broad humps corresponding to the amorphous phase after background subtraction (including the water contribution to the broad peaks at $25-35^{\circ} 2 \theta$ and $40-45^{\circ} 2 \theta$ ).

\section{In situ ESEM analysis}

An FEI Quanta 400 ESEM equipped with a Peltier stage was used to investigate the microstructural features of calcium carbonate phases precipitated after partial carbonation of 5$10 \mu \mathrm{L}$ droplets of $\mathrm{Ca}(\mathrm{OH})_{2}$ saturated solution with and without CA exposed to air for 2 to $7 \mathrm{~min}$. Afterwards the ambient air was progressively replaced by water vapor in the ESEM chamber $\left(p \mathrm{H}_{2} \mathrm{O}=6.5\right.$ torr at $\left.3^{\circ} \mathrm{C}\right)$. To simulate the evolution of the system during continuous evaporation of solution droplets (i.e., as occurs in air during in situ optical microscopy, XRD and micro-Raman experiments) water was allowed to evaporate from the sample by lowering $p \mathrm{H}_{2} \mathrm{O}$ to 2.5 torr at $3{ }^{\circ} \mathrm{C}$, while collecting secondary electron images. EDS microanalyses were performed using an xFlash 6/30 detector (Bruker) coupled to the ESEM.

\section{Ex situ TG/DSC, XRD, FTIR and FESEM analyses}

Pure CA protein and solids collected at different time intervals during both droplet and batch reactor carbonation experiments were subjected to simultaneous TG and DSC analysis on a Mettler-Toledo mod. TGA/DSC1. About 10-20 mg sample mass was deposited on $\mathrm{Al}$ crucibles and analyzed under flowing air $\left(100 \mathrm{~mL} \min ^{-1}\right)$ at a $10{ }^{\circ} \mathrm{C} \min ^{-1}$ heating rate, from 25 to $950{ }^{\circ} \mathrm{C}$ (TG) or 25 to $400{ }^{\circ} \mathrm{C}$ (DSC). Additionally, solids were deposited on zero-background $\mathrm{Si}$ sample holders and analyzed on a PANalytical X'Pert Pro X-ray diffractometer with $\mathrm{Cu} K \alpha$ radiation $(\lambda=1.5405 \AA$ ), in the $3-70^{\circ} 2 \theta$ range at a scanning rate of $0.002^{\circ} 2 \theta \mathrm{s}^{-1}$. The pure protein and precipitates were also analyzed on a JASCO 6200 FTIR spectrometer (frequency range $400-4000 \mathrm{~cm}^{-1}$; 
$1 \mathrm{~cm}^{-1}$ spectral resolution) equipped with an attenuated total reflectance (ATR) device for spectra collection without sample preparation (i.e., minimizing artifacts such as dehydration of ACC). Carbonates and protein FTIR bands were assigned according to the literature. ${ }^{63,64}$ Finally, solids were observed at high magnification using a FESEM (Zeiss Supra40VP or Zeiss Gemini). Samples were carbon coated prior to FESEM observation.

\section{TEM analysis}

Analysis of the morphology, size, and ultrastructure of ACC precursor phases, protein supramolecular structures and crystalline calcium carbonate phases was performed by means of TEM using a Philips CM20, operated at $200 \mathrm{kV}$ and a FEI Titan, operated at $300 \mathrm{kV}$. Prior to TEM observations, 25-200 $\mu \mathrm{L}$ droplets of saturated $\mathrm{Ca}(\mathrm{OH})_{2}$ solution were deposited on PVC crystallization dishes and exposed to air at room $T$. Following $3 \mathrm{~s}$ to $60 \mathrm{~min}$ of air exposure, calcium carbonate precipitation was quenched by addition of ethanol. Solids collected at different times from droplet experiments as well as batch carbonation experiments subjected to ethanol quenching (and subsequent drying) or freeze-drying were also analyzed following dispersion in ethanol. Alcohol dispersions were deposited on carbon/Formvar ${ }^{\circledR}$ film coated $\mathrm{Cu}$ grids. No significant textural or microstructural differences were observed in ACC and $\mathrm{CaCO}_{3}$ crystalline phases when comparing samples prepared following ethanol quenching $v s$. freeze-drying. TEM observations were performed using a $40 \mu \mathrm{m}$ (CM20) or a $30 \mu \mathrm{m}$ (Titan) objective aperture. SAED patterns were collected using a $10 \mu \mathrm{m}$ aperture, which allowed collection of diffraction data from an area of $\sim 0.2 \mu \mathrm{m}$ in diameter. In situ decomposition of ACC due to focused electron beam irradiation was also observed in the TEM. In the case of the CM20 equipment, the electron flux was maximized using a large $(200 \mu \mathrm{m})$ condenser aperture and a focused beam spot size of $\sim 200 \mathrm{~nm}$, thus providing an estimated electron flux of $c a$. 50-70 $\mathrm{A} \mathrm{cm}^{-2}$. Under these conditions, full conversion was achieved after $\sim 90 \mathrm{~s}$ of exposure. In the case of the Titan equipment, decomposition was achieved following $\sim 30 \mathrm{~s}$ of focused e-beam exposure. EDS microanalyses were performed in scanning-TEM mode (STEM). In the case of the Titan TEM $(300 \mathrm{kV})$, Z-contrast imaging was performed using a HAADF detector (STEM mode).

\section{Calculation of the saturation index using PHREEQC}

The time evolution of solution speciation and saturation index, SI $\left(\mathrm{SI}=\log \left(\mathrm{IAP} / K_{\mathrm{sp}}\right)\right.$, where IAP and $K_{\mathrm{sp}}$ are the ion activity product and solubility product of a relevant phase, respectively) with respect to the crystalline anhydrous $\mathrm{CaCO}_{3}$ polymorphs observed in our experiments (vaterite and calcite), as well as hydrated and anhydrous ACC, was calculated using the PHREEQC computer code ${ }^{65}$ for the different values of $\mathrm{pH},[\mathrm{Ca}]$, and dissolved $\left[\mathrm{CO}_{2}\right]$ determined experimentally. All calculations were performed considering
STP conditions. For the calculation of the SI, we used the protocol and published $K_{\text {sp }}$ values of calcite, vaterite, hydrated ACC and anhydrous ACC compiled elsewhere. ${ }^{28}$

\section{AFM imaging of calcite growth using a fluid cell}

In situ observations were performed using a Digital Instruments Nanoscope III Multimode AFM equipped with a fluid cell and working in contact mode under ambient conditions $\left(20 \pm 1{ }^{\circ} \mathrm{C}\right)$. The solutions $\left(2 \mathrm{~mL}\right.$ of $\mathrm{CaCl}_{2}+$ $\mathrm{NaHCO}_{3}$ growth solution with $\mathrm{pH} 8.14$ and $\mathrm{SI}_{\text {calcite }}=0.77$ with or without $1.5 \mu \mathrm{M} \mathrm{CA}$ ) were injected from a syringe coupled to an O-ring sealed fluid cell containing a freshly cleaved optical quality calcite crystal (placed with the (10.4) cleavage plane parallel to the bottom of the fluid cell). AFM images were collected using fresh $\mathrm{Si}_{3} \mathrm{~N}_{4}$ tips (Veeco Instruments, tip model NPS20) and analyzed with Nanoscope software (version 1.40). Special care was taken to avoid contact of the CA-containing growth solution with atmospheric $\mathrm{CO}_{2}$ (i.e., $\mathrm{N}_{2}$ flushing of solutions and no head or empty spaces in the fluid cell) to prevent any possible increase in DIC and SI during AFM imaging due to the catalytic effect of CA. Experiments were performed at least in triplicate. Measurement of the step spreading speed involved a minimum of 6 measurements per run.

\section{Calcium potentiometric titration}

Titration experiments were performed at $\mathrm{pH} 9.75$ on a Titrino 905 (Methrom) following the method outlined elsewhere. ${ }^{3}$ In brief, a $10 \mathrm{mM} \mathrm{CaCl}$ solution was continuously dosed to a $10 \mathrm{mM} \mathrm{Na} \mathrm{CO}_{3}$ buffer $(50 \mathrm{~mL})$ at a rate of $10 \mu \mathrm{L} \mathrm{s}^{-1}$. A 10 $\mathrm{mM} \mathrm{NaOH}$ solution (Sigma-Aldrich) was dosed using an automatic burette to keep the $\mathrm{pH}$ constant during the experiments, which were performed under continuous magnetic stirring $(150 \mathrm{rpm})$ at $25{ }^{\circ} \mathrm{C}$ (water-cooled jacketed reactor). Before addition of the $\mathrm{CaCl}_{2}$ solution and during all the titration experiments, $\mathrm{N}_{2}$ gas was continuously flowed over the buffer solution at a rate of $30 \mathrm{~L} \mathrm{~h}^{-1}$ in order to prevent the presence of $\mathrm{CO}_{2}$ in the reactor. The $\mathrm{Ca}^{2+}$ potential (i.e., activity of free-Ca) was continuously measured using an ion-selective electrode (ISE, Mettler-Toledo, DX337-Ca). The $\mathrm{pH}$ was measured using a glass electrode (Unitrode, Methrom) with a Pt1000 sensor for $T$ monitoring. Solution conductivity (5-ring conductivity measuring cell 856, Methrom) and transmittance at $610 \mathrm{~nm}$ (Optrode, Methrom) were also continuously recorded. Prior to titration experiments, the $\mathrm{Ca}$ selective probe was calibrated by addition of $10 \mathrm{mM} \mathrm{CaCl}$ solution to MilliQ water $(50 \mathrm{~mL})$ at a constant rate of $5 \mu \mathrm{L} \mathrm{s}^{-1}$, maintaining the $\mathrm{pH}$ constant at 9.75 using $10 \mathrm{mM} \mathrm{NaOH}$. A minimum of 3 replicate runs per experiment (with and without $1.5 \mu \mathrm{M}$ CA addition to the carbonate buffer solution) were performed.

\section{Circular dichroism}

CD spectrometry was done using a Jasco J-815 spectropolarimeter equipped with a Peltier stage. Near (240- 
$320 \mathrm{~nm})$ and far (190-240 nm) UV CD spectra were collected for $5 \mu \mathrm{M}$ CA solutions incubated for over $1 \mathrm{~h}$ in the following buffers: (1) DI water at the natural $\mathrm{pH}$ of the protein (6.5) as well as at $\mathrm{pH} 9.75$ and $12(\mathrm{pH}$ adjusted adding $100 \mathrm{mM}$ $\mathrm{NaOH}$ ); (2) the same as that of (1) but with $10 \mathrm{mM} \mathrm{CaCl}_{2}$, at $\mathrm{pH} 8,9.75$, and 12; (3) the same as that of (1) but with 10 $\mathrm{mM} \mathrm{Na}_{2} \mathrm{CO}_{3}$, at $\mathrm{pH} \mathrm{8,9.75}$ and 12. In addition, we performed near- and far-UV CD analysis of solutions collected both at pre- (60 $\mathrm{min})$ and post-nucleation (400 $\mathrm{min})$ stages during calcium potentiometric titration tests (precipitation runs performed at $\mathrm{pH} 9.75$ in the presence of $1.5 \mu \mathrm{M} \mathrm{CA}$ ). For near-UV and far-UV CD we used a quartz cell with a $10 \mathrm{~mm}$ and $1 \mathrm{~mm}$ path length, respectively. Spectra were collected at $25{ }^{\circ} \mathrm{C}$, with $64 \mu \mathrm{s}$ collection time, 5 iterations, and $1 \mathrm{~nm}$ spectral resolution. CD spectra analysis and band assignment was done following the literature. ${ }^{38}$ The percentage of CA secondary structures ( $\alpha$-helix, $\beta$-turn, $\beta$-strand and random coil) was determined from the deconvolution of far-UV CD spectra using the online BeStSel program. ${ }^{66}$

\section{CA esterase activity}

The loss of CA enzymatic activity during calcium carbonate precipitation was determined by monitoring the initial rate of hydrolysis of $p$-nitrophenyl acetate $(p N P A)$ at $25{ }^{\circ} \mathrm{C}$. Solution aliquots collected during calcium potentiometric titration tests (at $60 \mathrm{~min}$ and $400 \mathrm{~min}$ ) performed in the presence of $1.5 \mu \mathrm{M}$ CA were subjected to esterase activity tests using the method described elsewhere. ${ }^{67}$ In brief, $3 \mathrm{mM}$ $p$ NPA stock solutions were prepared. A reference test (for background subtraction) was performed by adjusting the $\mathrm{pH}$ of the stock solution to 9.75 with a phosphate buffer right before measuring for $2 \mathrm{~min}$ the absorbance at $405 \mathrm{~nm}$ using a Thermo Spectronic UNICAM UV spectrometer. Subsequently, $1 \mathrm{~mL}$ samples collected from the titration experiments were dosed to $1 \mathrm{~mL}$ of $3 \mathrm{mM} p \mathrm{NPA}$ with $\mathrm{pH}$ adjusted to 9.75 and the absorbance at $405 \mathrm{~nm}$ was measured right away for $2 \mathrm{~min}$. The catalytic esterase activity of the pure CA enzyme $(1.5 \mu \mathrm{M}$ CA in DI water with $\mathrm{pH}$ adjusted to 9.75 with a phosphate $+\mathrm{NaOH}$ buffer) was also measured following the above procedure. Changes in catalytic activity were calculated by measuring the \% change in the slope of the absorbance vs. time curves, after correction by the enzyme-free $p$ NPA reference curve.

\section{Author contributions}

CRN conceived the project; ERA, AIV and OZ designed and performed most of the precipitation experiments; ERA, KE and CRN performed FESEM, FTIR, TG/DSC and TEM analyses; AIV and CRA performed potentiometric titration tests; ERA performed the PHREEQC modeling; AIV performed $\mathrm{CD}$ analyses and enzyme activity tests; ABC performed AFM experiments. All the authors contributed to the interpretation of results, and CRN wrote the paper with inputs from all the authors.

\section{Competing financial interest}

The authors declare no competing financial interests.

\section{Conflicts of interest}

There are no conflicts to declare.

\section{Acknowledgements}

We thank the personnel of the Centro de Instrumentación Científica (CIC; University of Granada) for assistance with micro-Raman, FESEM, ESEM, TG/DSC, FTIR and TEM analyses. We also thank M. Schiro, B. Jamtveit and A. Putnis for comments and suggestions, C. V. Putnis for her help with AFM analyses, K. van Balen for his continuous support, and F. Conejero-Lara for his help with CD analyses. This work was financially supported by the Belgium Research Foundation Flanders (FWO), the Spanish Government (Grants CGL201570642-R and RTI2018-099565-B-I00), the Junta de Andalucía (Research Group RNM-179 and Project P11-RNM-7550), and the University of Granada ("Unidad Científíca de Excelencia" UCE-PP2016-05).

\section{References}

1 E. M. Pouget, P. H. H. Bomans, J. A. C. M. Goos, P. M. Frederik, G. de With and N. A. J. M. Sommerdijk, Science, 2009, 323, 1455-1458.

2 W. Dreybrodt, L. Eisenlohr, B. Madry and S. Ringer, Geochim. Cosmochim. Acta, 1997, 61, 3897-3904.

3 D. Gebauer, A. Völkel and H. Cölfen, Science, 2008, 322, 1819-1822.

4 L. B. Gower, Chem. Rev., 2008, 108, 4551-4627.

5 F. C. Meldrum and H. Cölfen, Chem. Rev., 2008, 108, 4332-4432.

6 C. Rodriguez-Navarro, E. Ruiz-Agudo, J. Harris and S. E. Wolf, J. Struct. Biol., 2016, 196, 260-287.

7 S. Y. Bahn, B. H. Jo, Y. S. Choi and H. J. Cha, Sci. Adv., 2017, 3, e1700765.

8 T. Mass, A. J. Giuffre, C. Y. Sun, C. A. Stifler, M. J. Frazier, M. Neder, N. Tamura, C. V. Stan, M. A. Marcus and P. U. P. A. Gilbert, Proc. Natl. Acad. Sci. U. S. A., 2017, 114, E7670-E7678.

9 F. Sebastiani, S. L. Wolf, B. Born, T. Q. Luong, H. Cölfen, D. Gebauer and M. Havenith, Angew. Chem., Int. Ed., 2017, 56, 490-495.

10 H. Du and E. Amstad, Angew. Chem., Int. Ed., 2019, 131, DOI: 10.1002/anie.201903662.

11 D. Athanasiadou, W. Jiang, D. Goldbaum, A. Saleem, K. Basu, M. S. Pacella, C. F. Böhm, R. R. Chromik, M. T. Hincke, A. B. Rodríguez-Navarro, H. Vali, S. E. Wolf, J. J. Gray, K. H. Bui and M. D. McKee, Sci. Adv., 2018, 4, eaar3219.

12 J. Seto, Y. Ma, S. A. Davis, F. Meldrum, A. Gourrier, Y.-Y. Kim, U. Schilde, M. Sztucki, M. Burghammer, S. Maltsev, C. Jäger and H. Cölfen, Proc. Natl. Acad. Sci. U. S. A., 2012, 109, 3699-3704. 
13 A. Rao, T. Roncal-Herrero, E. Schmid, M. Drechsler, M. Scheffner, D. Gebauer, R. Kröger and H. Cölfen, ACS Cent. Sci., 2019, 5, 357-364.

14 M. Jehannin, A. Rao and H. Cölfen, J. Am. Chem. Soc., 2019, 141, 10120-10136.

15 K. M. Wilbur and L. H. Jodrey, Biol. Bull., 1955, 108, 359-365.

16 W. Dreybrodt, J. Lauckner, L. Zaihua, U. Svensson and D. Buhmann, Geochim. Cosmochim. Acta, 1996, 60, 3375-3381.

17 W. E. Müller, H. C. Schröder, U. Schlossmacher, M. Neufurth, W. Geurtsen, M. Korzhev and X. Wang, FEBS Open Bio, 2013, 3, 357-362.

18 V. M. Krishnamurthy, G. K. Kaufman, A. R. Urbach, I. Gitlin, K. L. Gudiksen, D. B. Weibel and G. M. Whitesides, Chem. Rev., 2008, 108, 946-1051.

19 A. Bertucci, A. Moya, S. Tambutté, D. Allemand, C. T. Supuran and D. Zoccola, Bioorg. Med. Chem., 2013, 21, 1437-1450.

20 K. Karakostis, I. Zanella-Cléon, F. Immel, N. Guichard, P. Dru, T. Lepage, L. Plasseraud, V. Matranga and F. Marin, J. Proteomics, 2016, 136, 133-144.

21 S. A. Nielsen and E. Frieden, Comp. Biochem. Physiol., Part B: Biochem. Mol. Biol., 1972, 41, 461-468.

22 H. Miyamoto, T. Miyashita, M. Okushima, S. Nakano, T. Morita and A. Matsushiro, Proc. Natl. Acad. Sci. U. S. A., 1996, 93, 9657-9660.

23 R. Perfetto, S. Del Prete, D. Vullo, G. Sansone, C. Barone, M. Rossi, C. T. Supuran and C. Capasso, J. Enzyme Inhib. Med. Chem., 2017, 32, 632-639.

24 M. A. Rahman, T. Oomori and T. Uehara, Mar. Biotechnol., 2008, 10, 31-38.

25 K. Mann, B. Maček and J. V. Olsen, Proteomics, 2006, 6, 3801-3810.

26 G. M. Bond, J. Stringer, D. K. Brandvold, F. A. Simsek, M. G. Medina and G. Egeland, Energy Fuels, 2001, 15, 309-316.

27 R. G. Khalifah, Biol. Chem., 1971, 246, 2561-2573.

28 C. Rodriguez-Navarro, K. Kudłacz, Ö. Cizer and E. RuizAgudo, CrystEngComm, 2015, 17, 58-72.

29 M. Molva, S. Kilic and E. Ozdemir, Energy Fuels, 2016, 30, 10686-10695.

30 K. Lee, W. Wagermaier, A. Masic, K. P. Kommareddy, M. Bennet, I. Manjubala, S.-W. Lee, S. B. Parl, H. Cölfen and P. Fratzl, Nat. Commun., 2012, 3, 725.

31 S. Bentov, C. Brownlee and J. Erez, Proc. Natl. Acad. Sci. U. S. A., 2009, 106, 21500-21504.

32 X. Wang, W. Conway, R. Burns, N. McCann and M. Maeder, J. Phys. Chem. A, 2009, 114, 1734-1740.

33 J. J. De Yoreo, P. U. P. A. Gilbert, N. A. J. M. Sommerdijk, R. L. Penn, S. Whitelam, D. Joester, H. Zhang, J. D. Rimer, A. Navrotsky, J. F. Banfield, A. F. Wallace, F. M. Michel, F. C. Meldrum, H. Cölfen and P. M. Dove, Science, 2015, 349, aaa6760.

34 G. Fu, S. R. Qiu, C. A. Orme, D. E. Morse and J. J. De Yoreo, Adv. Mater., 2005, 17, 2678-2683.

35 A. Picker, M. Kellermeier, J. Seto, D. Gebauer and H. Cölfen, Z. Kristallogr. - Cryst. Mater., 2012, 227, 744-757.
36 H. Du, M. Steinacher, C. Borca, T. Huthwelker, A. Murello, F. Stellacci and E. Amstad, J. Am. Chem. Soc., 2018, 140, 14289-14299.

37 C. Rodriguez-Navarro, A. Burgos-Cara, K. Elert, C. V. Putnis and E. Ruiz-Agudo, Cryst. Growth Des., 2016, 16, 1850-1860.

38 S. M. Kelly and N. C. Price, Curr. Protein Pept. Sci., 2000, 1, 349-384.

39 J. Rieger, T. Frechen, G. Cox, W. Heckmann, C. Schmidt and J. Thieme, Faraday Discuss., 2007, 136, 265-277.

40 A. F. Wallace, L. O. Hedges, A. Fernandez-Martinez, P. Raiteri, J. D. Gale, G. A. Waychunas, S. Whitelam, J. F. Banfield and J. J. De Yoreo, Science, 2013, 341, 885-889.

41 Z. Zou, W. J. Habraken, L. Bertinetti, Y. Politi, A. Gal, S. Weiner, L. Addadi and P. Fratzl, Adv. Mater. Interfaces, 2017, 4, 1600076.

42 P. R. ten Wolde and D. Frenkel, Science, 1997, 277, 1975-1978.

43 I. Perovic, A. Verch, E. P. Chang, A. Rao, H. Cölfen, R. Kröger and J. S. Evans, Biochemistry, 2014, 53, 7259-7268.

44 G. Jain, M. Pendola, Y. C. Huang, D. Gebauer and J. S. Evans, Biochemistry, 2017, 56, 2663-2675.

45 M. Takizawa, Y. Sazuka, K. Horigome, Y. Sakurai, S. Matsui, H. Minato, T. Kureha and D. Suzuki, Langmuir, 2018, 34, 4515-4525.

46 S. Lee, S. G. Lee, D. Kwak, J. H. Park and K. Cho, J. Phys. Chem. C, 2011, 115, 2026-2029.

47 C. A. Haynes and W. Norde, Colloids Surf., B, 1994, 2, 517-566.

48 S. Mann, S. B. Parker, M. D. Ross, A. J. Skarnulis and R. J. P. Williams, Proc. R. Soc. London, Ser. B, 1983, 218, 415-424.

49 D. A. Walters, B. L. Smith, A. M. Belcher, G. T. Paloczi, G. D. Stucky, D. E. Morse and P. K. Hansma, Biophys. J., 1997, 72, 1425-1433.

50 I. W. Kim, M. R. Darragh, C. Orme and J. S. Evans, Cryst. Growth Des., 2006, 6, 5-10.

51 S. Elhadj, E. A. Salter, A. Wierzbicki, J. J. De Yoreo, N. Han and P. M. Dove, Cryst. Growth Des., 2006, 6, 197-201.

52 C. A. Orme, A. Noy, A. Wierzbicki, M. T. McBride, M. Grantham, H. H. Teng, P. M. Dove and J. J. DeYoreo, Nature, 2001, 411, 775-779.

53 S. Weiner and L. Addadi, Trends Biochem. Sci., 1991, 16, 252-256.

54 Y. Y. Kim, A. S. Schenk, J. Ihli, A. N. Kulak, N. B. Hetherington, C. C. Tang, W. W. Schmahl, E. Griesshaber, G. Hyett and F. C. Meldrum, Nat. Commun., 2014, 5, 4341.

55 D. A. Prokhorov, A. A. Timchenko, V. N. Uversky, V. S. Khristoforov, H. Kihara, K. Kimura and V. P. Kutyshenko, Biochim. Biophys. Acta, Proteins Proteomics, 2008, 1784, 834-842.

56 T. Chen, P. Shi, Y. Li, J. Zhang, T. Duan, Y. Yu, J. Zhou and W. Zhu, J. Cryst. Growth, 2018, 493, 51-57.

57 T. Chen, P. Shi, Y. Li, T. Duan, Y. Yu, X. Li and W. Zhu, CrystEngComm, 2018, 20, 2366-2373.

58 A. Rana, T. P. Gupta, S. Bansal and B. Kundu, Biochim. Biophys. Acta, Proteins Proteomics, 2008, 1784, 930-935.

59 Ö. Cizer, E. Ruiz-Agudo and C. Rodriguez-Navarro, Int. J. Archit. Herit., 2018, 12, 779-789. 
60 D. J. Jackson, L. Macis, J. Reitner, B. M. Degnan and G. Wörheide, Science, 2007, 316, 1893-1895.

61 A. Moya, S. Tambutté, A. Bertucci, E. Tambutté, S. Lotto, D. Vullo, C. T. Supuran, D. Allemand and D. Zoccola, J. Biol. Chem., 2008, 283, 25475-25484.

62 N. Le Roy, D. J. Jackson, B. Marie, P. Ramos-Silva and F. Marin, Front. Zool., 2014, 11, 75.

63 F. A. Andersen and L. Brecevic, Acta Chem. Scand., 1991, 45, 1018-1024.

64 M. Jackson and H. H. Mantsch, Crit. Rev. Biochem. Mol. Biol., 1995, 30, 95-120.
65 D. L. Parkhurst and C. A. J. Appelo, User Guide to PHREEQC (version 2) - A Computer Program for Speciation, Batch Reaction, One Dimensional Transport, and Inverse Geochemical Calculations (U.S. Geological Survey WaterResources Investigation Report 99-4259; Denver, Colorado), 1999.

66 A. Micsonai, F. Wien, L. Kernya, Y. H. Lee, Y. Goto, M. Réfrégiers and J. Kardos, Proc. Natl. Acad. Sci. U. S. A., 2015, 112, E3095-E3103.

67 J. M. Armstrong, D. V. Myers, J. A. Verpoorte and J. T. Edsall, J. Biol. Chem., 1966, 241, 5137-5149. 